\title{
TILTRÆEDELSESFOREL/ESNINGER
}

\section{TRE PROFESSORER}

Den 21. januar 2011 afholdt hele tre nye professorer deres tiltrædelsesforelæsninger på Afdeling for Antropologi og Etnografi, Aarhus Universitet.

Nils Bubandt, Rane Willerslev og Andreas Roepstorff løftede i deres forelæsninger sløret for, hvordan antropologien inden for deres respektive felter skal forme sig i fremtiden.

Tidsskriftet Antropologi glæder sig over at kunne viderebringe disse overvejelser til dem, der ikke kunne være til stede ved selve forelæsningerne, og til fremtidens læsere! 


\section{DEMOKRATI SOM SELVFØLGE}

Hvad kan antropologi sige om globaliseringen af folkestyret?

\section{NILS BUBANDT}

Efter sigende skrev en af demonstranterne ved studenterdemonstrationerne $i$ Beijing i 1989 følgende graffiti på en væg ved Den Himmelske Freds Port:

„Jeg ved ikke, hvad demokrati betyder, men vi vil gerne have mere af det!“ (Dalton et al. 2008:2).

Demokrati er tidens løsen - en ny global politisk selvfølgelighed båret af en ny slags global normativitet. Demokrati er et ubetinget gode. I sin tale til nationen i 2002, hvor George Bush omtalte Iran, Irak og Nordkorea som „ondskabens akse“, slog han også fast, at „ondskab var virkelig“, og at dens modsætninger var frihed og demokrati. ${ }^{1}$ Frihed og demokrati er tidens "Store Ideer", idealer, som ikke kun er gode for os, men som også i høj grad er blevet en mirakelkur, andre bør tage for deres problemer (Comaroff \& Comaroff 1999). På den måde har „demokrati“ erstattet ældre begreber som „civilisation“ og „modernitet“ og har fornyet ideen om Vestens mission civilisatrice (Pitts 2006). Den store udfordring ved at studere demokrati antropologisk er derfor at få en distance til de selvfølgeligheder, der er indskrevet i denne globale, politiske normativitet. Det må være muligt at studere demokratiets selvfølgeligheder på en ikke-normativ måde uden at skulle tvinges ind i et moralsk valg mellem Bush og Al-Qaeda. Andre er allerede begyndt at studere dette (se f.eks. Gaonkar 2007; Paley 2008), og på Afdeling for Antropologi og Etnografi er der allerede en gruppe folk, som er interesseret $i$ at opdyrke en ,demokratiets etnografi“. Gruppen inkluderer blandt andet Steffen Dalgaard, Thomas Fibiger og Maj Nygaard-Christensen. Og jeg vil inddrage nogle af de spændende ting, som de har lavet, fordi jeg synes, de fører samme sted hen, hvor jeg gerne vil hen. Og det er det sted, jeg godt vil tegne et billede af for jer i dag. 


\section{Fra lokale til globale selvfølgeligheder}

Antropologi tilbyder en tilgang til at komme både demokratiets hverdagsliv og dets globale selvfølgelighed nærmere, fordi antropologien altid har været interesseret i ,selvfølgeligheder“. En selvfølge er noget, der følger af sig selv. Noget, der derfor ikke behøver en forklaring, fordi det ,giver sig selv“ (Bourdieu 1977: 167). En selvfølgelighed er med andre ord et kulturelt faktum, garanteret af en kulturel logik.

I forbindelse med min ph.d. studerede jeg i begyndelsen af 1990'erne hekseri i det østlige Indonesien i en landsby, der hedder Buli. Hekseri er omgivet af en masse selvfølgeligheder i Vesten: Det er noget med undertrykkelsen af kvinder, noget middelalderligt overtro eller primitivt nonsens. I Buli er hekseri ikke nonsens, det er et virkeligt onde, men det er også et paradoksalt onde. Hekse (gua) er mennesker, som er besat af en ,skygge“ eller ånd, og som derfor bliver kannibaler med en ubændig sult efter menneskelever. Men samtidig er det hekseri, der har grundlagt den ø, Buli ligger på. Bjergene, uden hvilke havet ville oversvømme øen, er forsteninger af de kæmper, der i mytisk tid blev dræbt af hekse (Bubandt 1998). Så hekseri er noget skidt, fordi det slår folk ihjel, men samtidig er det noget nødvendigt skidt, fordi livet på øen ville have været umuligt uden hekseri.

Hekseri er en lokal kulturel selvfølge i Buli, på samme måde som demokrati er blevet en global, men lige så kulturel selvfølge i de sidste 30 år i det meste af verden. Og de paradokser, der er indbygget i de to selvfølgeligheder, ligner, vil jeg hævde, hinanden. Skiftet fra hekseri til demokrati er derfor slet ikke så langt, som man skulle tro, og det følger en trend i antropologien. Marcus og Fischer beskriver det skifte, der er sket i de sidste 20-30 år, således:

Antropologiens projekt er ikke længere bare at opdage nye verdener, at oversætte det eksotiske til det velkendte ... Det er i stigende grad opdagelsen af verdener, der er allerede er velkendte, men som ingen af os forstår, og som vi alle er i gang med at prøve at udrede (Fischer \& Marcus 1999:xvii, min oversættelse).

Demokrati er et sådant fænomen, som på én gang er velkendt, men som ingen af os helt forstår, og som vi alle sammen - både i Indonesien og i Danmark - hele tiden er i gang med at prøve at få rede på. Det er derfor, vi konstant har diskussioner om ytringsfriheden, om forholdet mellem lighed og demokrati, om grænsen mellem lobbyisme og korruption og så videre.

Fordi demokrati eksporteres som en selvfølge, mener de fleste af os også, at vi ved, hvad det er... og at det er godt. Op mod 80 procent af folk i stort set alle lande mener således, at demokrati er den bedste styreform (Diamond 2008a:xi). Og de fleste kan hæfte nogle betydninger på begrebet „demokrati“. Cirka halv- 
delen siger, at demokrati handler om frihed (ytringsfrihed, frihed til politisk deltagelse osv.) eller bestemte politiske processer (valg, flertalsstyre osv.). Den anden halvdel er delt mellem at definere demokrati som lighed eller økonomisk fremgang og ikke at definere det overhovedet (Dalton, Shin \& Jou 2008:5).

Ikke alle er med andre ord helt sikre. I gennemsnit deler mellem 20 og 25 procent af alle adspurgte $i$ hele verden med andre ord den kinesiske demonstrants holdning: De ved ikke helt, hvad demokrati er, men de vil godt have mere af det. Selv blandt de 75-80 procent, som har et svar parat, der kan „distingvere“ dem som „vidende mennesker“, når de bliver spurgt, hvad demokrati er, vil jeg hævde, at der er en stor grad af selvfølgelighed i deres svar, og at disse svar ikke er dækkende for, hvordan de i praksis agerer „demokratisk“. Også her er der en parallel imellem hekseri og demokrati.

Lingoro Feplun er min adoptivfar i Buli og en rituel ekspert. Når han blev spurgt af vigtige personer som regeringsfolk eller tilrejsende antropologer, hvad hekse var for nogen, kunne han give en lang, detaljeret forklaring om, hvordan folk blev hekse, hvordan de spiste andres lever, og hvordan man bedst undgik at ende enten som heks eller offer for en heks. Men da hans kone døde af hekseri i 1997, og vi snakkede om hekse en aften, sagde han, at han ikke vidste noget som helst om hekse: Han havde personligt aldrig set én, og generelt var hekseri uden for menneskers erkendelse. Én ting er altså, hvad folk siger, de ved, og en anden ting er deres praktiske viden. Det gælder hekseri, og det gælder demokrati.

\section{Demokrati som epistemisk ideal}

Hidtil har studiet af demokrati dog i høj grad været styret af en interesse i, hvad folk siger om demokrati. Det har også været gennemsyret af det, som Pierre Bourdieu - med vanlig flair for at gøre det vanskelige endnu mere vanskeligt - kalder ,,skolastisk epistemocentrisme" (Bourdieu 2000:50). Skolastisk epistemocentrisme er ekspertens syn, et forsøg på at skabe universelle modeller, at definere et fænomen $i$ alle dets abstrakte muligheder uden kontekst, at tage udgangspunkt $i$ epistemisk viden, i epistemet. Bær lige over med mig i 30 sekunder mere, så skal jeg nok blive konkret. Epistèmè kommer fra græsk filosofi. Aristoteles skelnede imellem forskellige typer af intellektuel viden eller dyder (Aristotle 2009; Salkever 2009: 220 nævner i hvert fald otte typer). Af dem vil jeg bare fremhæve tre, nemlig teoretisk viden (epistèmè), teknisk viden (technê) og praktisk viden (phronêsis) (se Flyvbjerg 2001).

Epistèmè, eller teoretisk viden, var for Aristoteles den højeste form for viden. Kun den kunne lede til filosofisk visdom, den mest nyttige form for menneskeligt virke, fordi det indebar det største potentiale for lykke. Jeg har aldrig selv mødt 
en lykkelig filosof, men lad nu det ligge, det var det, han mente. Epistèmè angik for Aristoteles de evige ting. Det var den teoretiske form, der ligger under alt det, vi umiddelbart kan erkende. Og det er denne søgen efter den abstrakte form, der ligger uden for social kontekst, som er blevet et videnskabeligt ideal - også i samfundsvidenskaben - og som Bourdieu kalder „epistemocentrisme“.

Der findes enormt mange rigtige gode analyser af demokrati i denne epistemiske forstand, som afdækker demokratiets essens eller ,ånd“ (Dahl 2000; Diamond 2008b; Tilly 2007), analyserer dets forskellige historiske former (Held 2006; Schumpeter 1947) og forholder sig kritisk til de forskellige grundlæggende teorier om demokrati (Cunningham 2005; Keane 2009; Lakoff 1996). Det er lærde bøger om, hvad lærde igennem tiden har ment om demokrati og om, hvordan den politiske elite har praktiseret det. Demokrati er dog med dette fokus blevet et skolastisk og epistemisk ideal, som eksisterende teorier og samfund kan måles imod. Og det er et epistemisk syn på demokrati, som også er blevet globaliseret som politisk faktum. Demokratiets essens ligger derfor - både i den samfundsvidenskabelige og i den realpolitiske optik - uden for tid og rum ... I den forstand findes demokrati kun „her og nu“, fordi det altid kan forbedres og dermed altid har sin virkelige virkelighed i en mulig fremtid. Jeg siger derfor ikke, at demokrati ikke er virkeligt eller ikke findes. Demokrati er meget virkeligt, institutionelt, geopolitisk og identitetsmæssigt for alle, der føler sig som borgere i et demokratisk samfund eller drømmer om at blive det. Derimod vil jeg med den franske filosof Jacques Derrida hævde, at demokratiets betydning som en virkelig politisk struktur altid er ustabil, fordi det - både for dem, der føler, de bebor et demokrati, og for dem, der gerne vil - altid og nødvendigvis har en transcendent karakter. Demokrati er kun demokratisk, så længe det er på vej til at blive forbedret. Demokratiets institutionelle virkelighed er derfor garanteret af den fremtid, hvori dets essens bliver realiseret. Demokrati, hævder Derrida, er derfor altid et uopfyldt potentiale, ,a democracy-to-come“ (Derrida 2005b:86ff.). Det er kun så længe, at det fastholder denne potentialitet eller transcendens, at demokrati som institutionel virkelighed kan bevare sin legitimitet. Demokrati er kun demokratisk, så længe det synes at love forbedring, og i dette potentiale ligger dets essens. Jeg vil påstå, at den epistemiske videnskab om demokrati accepterer demokratiets evige fremtidighed snarere end undersøger, hvordan denne tidslige selvfølgelighed er historisk og epistemologisk konstitueret.

På en måde kan man sige, at det netop er demokratiets evne til at åbne op for mulige fremtider, der giver demokratiet dets globale appel. Demokrati er vor tids utopi: Det inviterer os alle sammen til at drømme om en bedre verden, en anden fremtid, igen. Men der er mange slags tidsligheder, som drømmen om en demokratisk fremtid kan sættes ind i. Lad mig give et eksempel. 


\section{Demokratiets paradokser 1. Den udsatte fremtid}

Muddafar Syah er den 48. sultan af Ternate i det østlige Indonesien. Han er muslim, mystiker og politiker. Sultandømmet i Ternate blev grundlagt til 1200-tallet, men det har ifølge Muddafar Syah og hans cirka 100.000 loyale tilhængere på øen mytiske rødder tilbage til selve jordens skabelse. Den politiske struktur i sultandømmet er opbygget sådan, at der er repræsentanter fra de forskellige landsbyer i et råd (bobato), som styrer de verdslige forhold i sultandømmet, mens et andet råd styrer de religiøse $i$ en slags kosmopolitisk og urdemokratisk alliance. Men opbygningen ligner ifølge sultanens tilhængere også det moderne indonesiske parlaments to kamre, og det er der en god grund til.

For da de første europæere kom til denne del af Indonesien, der går under navnet „Krydderiøerne“, i begyndelsen af 1500-tallet, var de ifølge sultanen slet ikke på jagt efter nelliker og muskat. Deres „hemmelige mission“ var at stjæle sultandømmets politiske struktur, dets demokrati, for at kopiere systemet i Europa. Siden kom denne struktur så tilbage til Indonesien med den hollandske kolonimagt og uafhængigheden i 1949. Ternate - ikke Europa - er med andre ord verdens første demokrati. Opdagelsesrejserne er dermed, set fra Ternate, historien om Europas tyveri af demokratiet, mens nutiden er historien om forsøget på at sælge demokratiet tilbage til Ternate, som om det var en europæisk idé (Bubandt 2009b).

En sjov myte måske, fra en desperat og marginal politiker i et tredjeverdensland. Men Muddafar Syahs myte bør måske give anledning til, at vi tjekker vores egne myter om demokrati. Ifølge historikeren John Keane er det for eksempel en myte, at Athen var det første demokrati. Demokratiets oprindelse, som ord og som praksis, går både længere tilbage og længere østpå. Ikke helt til Ternate, men dog til sumererne og til mellemøstlige bystater i Iran, Irak og Syrien omkring 1500 år f.v.t - og altså 1000 år før de græske demokratier (Keane 2009: 111ff.). Mudaffar Syah har sandsynligvis ret i, at demokrati oprindeligt ikke er et europæisk fænomen. Og i hvert fald i Irak genimporteres det nu til landet som en europæisk idé. Som episteme er demokrati med andre ord fuld af myter, som er i gang med at blive universaliseret ... men altså ikke uden modstand.

Et godt nutidigt eksempel på den epistemiske tilgang, som universaliserer sin egen position for så at gøre den til en global sandhed, er det demokratiindeks, som den amerikanske organisation Freedom House hvert år udgiver. Der er i dag 194 lande i verden. Af disse er 89 lande ifølge Freedom House „frie“ og demokratiske. Det er 46 procent af verdens lande, en procentdel, der er vokset fra 27 procent i 1975 (Freedom 2010). Opgørelsen er lavet af et hold på 68 analytikere og eksperter. Hver af dem har ansvar for en antal lande og svarer på baggrund af medierapporter, samtaler med ngo'er og et landebesøg på 29 spørgsmål om- 
kring demokrati og frihed. En høj grad af rettigheder og frihed giver et 1-tal, mens en lav grad af rettigheder og frihed giver et 7-tal. Har det enkelte land en samlet score mellem 1 og 2,5, anses det for at være et frit og demokratisk land, mens det er delvist frit eller ufrit eller udemokratisk, hvis scoren er højere. Den demokratiske hensigt i undersøgelsen er god nok, men den giver ikke, som den selv hævder, en oversigt over ,den globale status for frihed, som den opleves af individuelle mennesker". ${ }^{2}$

Man får det, man spørger efter. Og kigger man på avisartikler og nyhedsudsendelser og taler man med ngo'er, får man altså journalisters og ngo-lederes mening om, hvordan det står til med friheden og demokratiet i et bestemt land. Dette er ikke repræsentative meninger, men derimod en meget bestemt slags individers oplevelse: en urban, uddannet, velstillet elites oplevelse. Det er med andre ord en skolastisk og epistemisk idé om demokrati, som Freedom House måler: en velstillet elites forståelse af et ideal, i forhold til hvilket eksisterende demokratier kan måles. Og graden af afvigelse fra dette ideal kan gives en numerisk og tilsyneladende objektiv værdi.

Jeg foreslår et sammenlignende studie af demokrati, som ikke starter med at opdele i „gode“ og „dårlige varianter, i „hele“ og „,halve“ demokratier. Et komparativt studie, der ikke sammenligner essenser, som en epistemisk form for viden vil gøre, men som sammenligner paradokser, som de udspiller sig i praksis i en foranderlig og modsætningsfyldt kontekst. Det er det, en phronetisk videnskab gør (Flyvbjerg 2001:58ff.), og antropologien er nok den mest phronetiske, den mest kontekstuelle af alle videnskaber (Bubandt \& Otto 2010). „Et phronetisk studie af demokrati“: Det lyder dyrt, men det handler egentlig bare om at tage sig tiden til at kigge etnografisk og komparativt på demokratiets hverdagsliv og forfølge det derhen, hvor det leves ... også uden for Folketinget og valgaftenen. Det, jeg vil forslå at sammenligne, er, hvordan demokratiets paradokser udfolder sig forskellige steder i verden.

\section{Demokratiets paradokser 2. Den besmittede renhed}

Jeg har allerede talt om det paradoks, der er bygget ind i demokratiets tidslighed, og at man kan sammenligne den måde, hvorpå demokrati inkorporeres i og lægger op til for skellige ideer om tid. Et andet af demokratiets paradokser handler om kampen for at holde det „rent" $i$ en „,forurenet“ verden. Og én af de ting, der „forurener" demokratiet, er penge. Lad mig give et eksempel.

Politikere i Papua New Guinea - som Steffen Dalsgård har undersøgt i sin ph.d.-afhandling - står med et problem (Dalsgaard 2009). De er demokratisk valgte og står til regnskab for en stat og en række internationale ngo'er, som ser 
nøje efter, om de forbryder sig mod landets korruptionslovgivning. Men de står også til regnskab over for vælgerne, som i høj grad mener, at politikerne er bundet af samme udvekslingsmoral, som skabte de traditionelle Big Men. På øen Manus ser vælgerne i hvert fald demokratiske valg i en udvekslingslogik og forventer derfor, at politikerne gengælder deres stemmer ved at give noget tilbage til landsbyen. Og man forsøger at indvikle politikerne i disse forventninger ved at behandle dem som Big Men eller lapan og overdænge dem med traditionelle gaver. Omvendt agerer politikerne selv som Big Men i forsøget på at kapre stemmer. En af måderne, de gør det på, er ved at uddele gaver fra en særlig personlig „cigarkasse“, som parlamentet har valgt at tildele politikerne, i erkendelse af at det nu engang er demokratiets vilkår i Papua Ny Guinea. Problemet er så, at politikerne konstant risikerer at blive anklaget for korruption af politiske modstandere, når de anvender disse midler.

Korruption er også demokratiets spøgelse andre steder i verden (Bubandt 2006). Som David Letterman sagde, da det i 2008 kom frem, at irakiske embedsmænd havde svindlet for flere milliarder dollars: „Gud, så de har faktisk fået et amerikansk demokrati!“ Demokrati producerer med andre ord nogle paradokser, som ganske vist globaliseres, men hvis udformning og håndtering i praksis ser forskellig ud forskellige steder i verden. Det er denne forskel, vi kan studere praktisk-etnografisk eller, som jeg her har kaldt det, ,phronetisk“ uden at tage udgangspunkt i et bestemt demokratisk ideal. Jeg har nævnt to paradokser, som jeg mener er indbygget $\mathrm{i}$ demokratiet, nemlig på den ene side demokrati som en evig fremtid, vi forgæves forsøger at bebo, og på den anden side demokrati som et „hygiejnisk problem“ - det er, som om demokrati hele tiden besmittes (af penge, selviskhed, paragrafrytteri eller ulighed), og at vi konstant, men forgæves forsøger at „rense“ det. Disse paradokser finder forskelligt udtryk i Papua New Guinea og i Indonesien, netop fordi demokrati globaliseres ideologisk og politisk retorisk som et epistemisk ideal, men oversættes og håndteres forskelligt de to steder. En analyse, der selv er optændt af at finde demokratiets essens, er netop i fare for at overse dette, at overse de sociale og historiske mekanismer, der på den ene side har gjort en bestemt kulturel idé om demokrati til en global selvfølgelighed, men som på den anden side også gør, at de paradokser, som eksporteres med denne globale selvfølgelighed, tager forskellig form forskellige steder. Det giver ofte demokratiet nogle lokale udtryksformer, som er både uventede og udfordrende. Lad mig give et eksempel.

Matams er, som Thomas Fibiger har studeret i sin ph.d.-afhandling, en slags forsamlingshuse for shiamuslimer, som i Bahrain fungerer som alternative offentlige rum, hvor folk drøfter dagligdags begivenheder og træffer fælles beslutninger (Fibiger 2010). Matams er i den forstand demokratiske rum, som min- 
der om de kaffehuse, som i 1700-tallet lagde grunden til civilsamfundet og det borgerlige demokrati i Europa (Habermas 1989). Men det skurrer måske i vores forståelse af demokrati at få at vide, at disse matams som regel har et billede af den afdøde iranske religiøse leder, ayatollah Khomeinei, på bagvæggen. Er Khomeinei og demokrati forenelige? Er islam og demokrati? Som Thomas Fibiger viser, er grænsen mellem det sekulære og det religiøse, imellem det demokratiske og det sekteriske, sværd at drage i Bahrain. Og paradoksalt nok er disse religiøse matams mere demokratiske end det sekulære parlament i Bahrain, fordi parlamentet er styret så hårdt af det regerende khalifadynasti, som i manges øjne bruger begreberne ,demokrati“ og „,sekularisme“ som slet skjult eufemismer for sunnidominans (Fibiger 2010).

Måske er det i forlængelse af dette eksempel værd at tænke over, om det skarpe skel imellem religion og demokrati i sig selv blevet en del af en sekulær teologi, en del af globaliseringen af det sekulære demokrati som epistemisk ideal (Bubandt \& Beek 2011)? Hvorfor er det egentligt så nødvendigt ... og så svært ... at udrense penge og religion fra demokrati? Og er de, som ikke udrenser politikerne på Papua New Guinea eller deltagerne i matams på Bahrain - per definition derfor mindre demokratiske? Eller kan man forestille sig forskellige varianter af demokrati - varianter, som ikke nødvendigvis følger det epistemiske ideal, der vokser ud af den euroamerikanske kulturhistorie?

\section{Demokrati som politisk teknologi}

Ud over at blive globaliseret som epistemisk ideal igennem medier, i internationale erklæringer og i politiske programmer bliver demokrati også globaliseret som institution igennem en form for technê eller politisk teknologi. Det er i denne modalitet, at demokrati har og hele tiden får bekræftet sin institutionelle virkelighed. Men globaliseringen af demokrati som institutionel virkelighed indebærer et tredje demokratisk paradoks, nemlig demokratiets tendens til at igangsætte mekanismer, der underminerer demokratiet selv. Det man kunne kalde demokratiets autoimmunitet. ${ }^{3}$

Inden den stort anlagte offensiv i Marjah-provinsen i februar 2010 annoncerede Stanley McChrystal, den militære øverstkommanderende i Afghanistan, at den militære operation ville blive efterfulgt øjeblikkeligt af en demokratisk regeringsstruktur. „Vi har en regeringsæske, 'a government-in-a-box', klar til at blive rullet ind," sagde McChrystal (Sanger 2010). Demokratiet var med andre ord færdigpakket og klargjort til at fratage Taleban deres lokale støtte.

At man kan installere en demokratisk politisk infrastruktur som en slags „militær præfabrikata“ lyder paradoksalt. Det gik da heller ikke som planlagt. 
Offensiven fejlede, og den afghanskbemandede politiske infrastruktur kom aldrig på benene. Taleban beholdt kontrollen i Marjah, mens McChrystal nogle måneder senere blev afsat af præsident Obama som øverstkommanderende for nogle kritiske bemærkninger til tidsskriftet Rolling Stone. Men McChrystals idé om at koble militær intervention og demokratisering kan findes mange andre steder.

Siden NATOs intervention i Kosovo-konflikten i 1999 er udvikling, militær intervention og demokratiopbygning blevet stadig mere sammenflettede. Treenigheden udgør i dag en politisk teknologi, som bringes i anvendelse til at håndtere „postkonfliktsituationer“ over hele verden (Duffield 2007; Paris 2004; Zeeuw \& Kumar 2006). Denne eksport af demokrati som en politisk teknologi skete i kølvandet på den demokratioptimisme, der prægede 1990'erne. De fleste politiske observatører mente, at globaliseringen indvarslede en lys fremtid for demokratiet. Globale forbindelser ville universalisere vestlige modeller for demokrati og skabe kulminationen af det, Huntington kaldte ,den tredje demokratiseringsbølge" (Huntington 1993). Efter Berlin-murens fald og socialismens kollaps ville resten af den politiske verdenshistorie være historien om demokratiets triumf (Fukuyama 1992). Og der var grund til optimisme: Fra 1975 til 1999 fordobledes antallet af „frie“ og demokratiske lande fra 41 til 88 (Freedom 2010). Demokrati blev det nye ord for udvikling eller modernisering. Det var ikke længere et nationalt, men et globalt anliggende (Held 2006: 293). Valgmonitorering, ngo'ernes stigende politiske indflydelse og multinationale organisationerne fokus på demokratiopbygning skabte et globalt „overvågningsdemokrati“, et monitory democracy (Keane 2009:706ff.). Demokrati og politisk rationalitet blev sammensmeltet til en ny slags kosmopolitisk govermentalitet (se Rose 1999).

Men siden 1999 er det begyndt at gå dårligt for den globale „Operation Demokrati“. I 2010 registrerede Freedom House 89 frie og demokratiske lande i verden, kun ét land mere end i 1999. Demokratiseringsbølgen blev ikke den politiske „tsunami“, man havde håbet i 1990'erne (Gaonkar 2007). Det skyldes ikke kun, at autoritære kræfter modarbejder demokratiets globalisering. Det virker derimod, som om demokrati i sig selv er med til at skabe de identitetspositioner, som er potentielt voldelige - etniske og religiøse forskelle for eksempel - og som underminerer demokratiet (Benhabib 1996; Chua 2004). Det virker, som om globaliseringen af demokrati har udviklet en autoimmun sygdom, at demokrati igangsætter nogle processer, som det selv er allergisk over for (Derrida 2003). Lad mig give et eksempel. 


\section{Demokratiets paradokser 3. Autoimmunitet}

Da østtimoreserne overvældende stemte for selvstændighed i 1999, efter i tre årtier at være besat af Indonesien, var forventningerne enorme - både i Østtimor og i FN, som påtog sig rollen at opbygget et demokrati i verdens nyeste nation. Godt fem år senere var landet ramt af politisk krise, optøjer og en stigende etnisk modsætning mellem folk i øst og folk i vest. Som Maj Nygaard-Christensen viser i sin ph.d.-afhandling, var det ironisk, at en befolkning, som i mere end 30 år havde lidt under politisk marginalisering fra Indonesien, fordi de boede på den østlige del af øen Timor, selv efter kun få år som en selvstændig nation skulle begynde at marginalisere folk, der kom fra Østtimors egne østligste provinser. Med den etniske og politiske uro blev det smerteligt klart - både i FN og for befolkningen i Østtimor - at demokratiets løfter om, at frihed automatisk ville medføre lighed og broderskab, ikke kunne holdes (Nygaard-Christensen 2010). På mange måder var det netop det demokratiske spil om fordelingen af magten, der førte til, at folk, der i 30 år havde været del af den samme modstandsbevægelse, nu ikke længere var hverken brødre eller lige.

Demokrati synes at love lighed af to slags på samme tid, nemlig politisk lighed og økonomisk lighed (Appadurai 2007). Og de fleste i Østtimor drømte om begge slags lighed i dagene efter uafhængigheden. Virkeligheden blev ikke sådan: Fattigdommen forblev stor, og tilstedeværelsen af ekstremt mange FNfolk gjorde den økonomiske ulighed endnu mere tydelig. Hvordan kan brødre være lige, hvis deres frihed også indebærer, at goderne er ulige fordelt? I Østtimor førte dette paradoks, som er indbygget i demokratiets globale appel, til en autoimmun reaktion: Nogen hører ikke til her. Men paradokset er globalt. For at nogen kan være lige, skal andre lukkes ude: dem i øst eller dem fra syd. Ikke alle kan jo være lige: Demokratiet må have en grænse. Demokratiets løfte om lighed indebærer med andre ord også behovet for eksklusion (Geschiere 2009) - nogle gange med vold, andre gang med bureaukratisk magt: Dette er demokratiets autoimmunitet.

\section{Konklusion. Vi har aldrig været demokratiske}

Som Churchill engang sagde: „Demokrati er den værste form for regering, bortset fra alle de andre former, som man har forsøgt sig med" (Diamond 2008a:x). Når jeg hævder, at demokrati er fuldt af paradokser, siger jeg derfor ikke noget nyt. Men et antropologisk blik på demokrati kan gøre os klogere på, hvordan demokrati kan være på én gang den værste og den eneste styreform. Kunne det være, at „,det værste“ og „det eneste“ i praksis er forbundne? At det er de samme mekanismer, 
der giver demokratiet dets globale appel, som forbinder det uløseligt med skuffelse? Måske er det demokratiets globalisering som et tiltrækkende epistemisk ideal, der reproducerer det som en umulighed - som skaber de sociale vilkår for, at demokrati leves som selvfølgelig virkelighed, der er hjemsøgt af tre former for „,udsættelse“ eller paradokser. Jeg har hævdet, at tre former for paradokser hjemsøger fornemmelsen af, at demokratiet er en „naturlig“ og „virkelig“ størrelse, nemlig at det samtidig med at demokrati som stabil og institutionel virkelighed garanteres af, at det er evigt udsat fremtidighed (som ikke helt kan bebos ,herog-nu“), en altid-allerede besmittet renhed (som konstant bør renses), en konstant autoimmunitet (som synes at producere sin egen modsætning)?

Det er den måde, demokratiets selvfølgelighed og globale virkelighed udmønter sig på som (uløselige?) paradokser i praksis, som jeg vil bruge de næste år på at undersøge, dels ved at fortsætte mit feltarbejde i Indonesien, blandt andet sammen med sultanen af Ternate (Bubandt 2009b), og dels ved at begynde feltarbejde blandt en global gruppe af europæere, der er konverteret til sufisme, og som har meget at sige om demokratiet og dets paradokser (Bubandt 2009a). Sammen med de andre på afdelingen vil jeg igennem etnografisk feltarbejde undersøge de paradokser, der udspringer af, at vi i forsøget på at leve op til demokrati som et uopnåeligt ideal aldrig er demokratiske (se Latour 1993).

\section{Noter}

1. Se hele talen på http://georgewbush-whitehouse.archives.gov/news/releases/2002/01/print/ 20020129-11.html.

2. Se metodediskussionen på hjemmesiden for Freedom House: http://www.freedomhouse.org/ template.cfm?page $=351 \&$ ana_page $=363 \&$ year $=2010$.

3. Denne opdeling af demokratiets paradokser i dets fremtidighed (futuricity), dets umulige renhed (impossible purity) og autoimmunitet er inspireret af Derrida (Cheah \& Guerlac 2009; Derrida 2005a, 2005b).

\section{Litteratur}

Appadurai, Arjun

2007 Hope and Democracy. Public Culture 19(1):29-34.

Aristotle

2009 The Nichomachean Ethics (with an introduction by Lesley Brown). Oxford: Oxford University Press.

Benhabib, Seyla

1996 Democracy and Difference. Contesting the Boundaries of the Political. Princeton: Princeton University Press. 
Bourdieu, Pierre

1977 Outline of a Theory of Practice. Cambridge: Cambridge University Press.

2000 Pascalian Meditations. Oxford: Polity.

Bubandt, Nils

1998 The Odour of Things: Smell and the Cultural Elaboration of Disgust in Eastern Indonesia. Ethnos 63(1):48-80.

2006 Sorcery, Corruption, and the Dangers of Democracy in Indonesia. Journal of the Royal Anthropological Institute 12(2):413-31.

2009a Gold for a Golden Age: Sacred Money and Islamic Emancipation in a Global Sufi Order. Social Analysis 53(1):103-22.

2009b Interview with an Ancestor: Spirit as Informants and the Politics of Possession in North Maluku. Ethnography 10(3):291-316.

Bubandt, Nils \& Martijn van Beek (eds.)

2011 Varieties of Secularism in Asia. Anthropological Explorations of Politics, Religion, and the Spiritual. London: Routledge.

Bubandt, Nils \& Ton Otto

2010 Anthropology and the Predicaments of Holism. I: T. Otto \& N. Bubandt (eds.):

Experiments in Holism. Theory and Practice in Contemporary Anthropology.

Oxford: Wiley-Blackwell.

Cheah, Pheng \& Suzanne Guerlac

2009 Introduction: Derrida and the Time of the Political. I: P. Cheah \& S. Guerlac (eds.): Derrida and the Time of the Political. Durham: Duke University Press.

Chua, Amy

2004 World on Fire: How Exporting Free Market Democray Breeds Ethnic Hatred and Global Instability. London: Bantam Doubleday.

Comaroff, John \& Jean Comaroff

1999 Introduction. I: J. Comaroff \& J. Comaroff (eds.): Civil Society and the Political Imagination in Africa. Chicago: The University of Chicago Press.

Cunningham, Frank

2005 Theories of Democracy. A Critical Introduction. London: Routledge.

Dahl, Robert

2000 On Democracy. New Haven: Yale University Press.

Dalsgaard, Steffen

2009 All the Government's Men. State and Leadership in Manus Province, Papua New Guinea. Ph.d.-afhandling. Aarhus Universitet.

Dalton, Russel J., Doh C. Shin \& Willy Jou

2008 How People Understand Democracy. I: L. Diamond \& M. Plattner (eds.): How People View Democracy. Baltimore: The Johns Hopkins University Press.

Derrida, Jacques

2003 Auto-Immunity: Real and Symbolic Suicides: A Dialogue with Jacques Derrida.

I: G. Borradori (ed.): Philosophy in a Time of Terror: A Dialogue with Jürgen

2005a The Politics of Friendship. London: Verso.

2005b Rogues. Two Essays on Reason. Stanford: Stanford University Press. 
Diamond, Larry

2008a Introduction. I: L. Diamond \& M. Plattner (eds.): How People View Democracy. Baltimore: The Johns Hopkins University Press.

2008b The Spirit of Democracy. The Struggle to Build Free Societies Throughout the World. New York: Henry Holt \& Companys.

Duffield, Mark

2007 Development, Security, and Unending War. Cambridge: Polity Press.

Fibiger, Thomas Brandt

2010 Engaging Pasts. Historicity and Political Imagination in Contemporary Bahrain. Ph.d.-afhandling. Aarhus Universitet.

Fischer, Michael M.J. \& George E. Marcus

1999 Introduction to the Second Edition. I: G.E. Marcus \& M.M.J. Fischer (eds.): Anthropology as Cultural Critique. Chicago: University of Chicago Press.

Flyvbjerg, Bent

2001 Making Social Science Matter: Why Social Inquiry Fails and How It Can Succeed Again. Cambridge: Cambrdige University Press.

Freedom House

2010 Freedom in the World. Country Rating. Washington. Freedom House. http:

//www.freedomhouse.org/images/File/CountryStatus and RatingsOverview19732010.pdf. Accessed 12 January 2010.

Fukuyama, Francis

1992 The End of History and the Last Man. New York: The Free Press.

Gaonkar, Dilip Parameshwar

2007 Cultures of Democracy. Public Culture 19(1). Durham: Duke University Press.

Geschiere, Peter

2009 The Perils of Belonging. Autochthony, Citizenship, and Exclusion in Africa and Europe. Chicago: The University of Chicago Press.

Habermas, Jürgen

1989 [1962] The Structural Transformation of the Public Sphere: An Inquiry into a Category of Bourgeois Society. Cambridge, MA: MIT Press.

Held, David

2006 Models of Democracy. Stanford: Stanford University Press.

Huntington, Samuel

1993 The Third Wave: Democratization in the Third World. Norman: University of Oklahoma Press.

Keane, John

2009 The Life and Death of Democracy. London: Simon \& Schuster.

Lakoff, Sanford

1996 Democracy. History, Theory, Practice. Boulder: Westview Press.

Latour, Bruno

1993 We Have Never Been Modern. New York: Harvester/ Wheatsheaf. 
Nygaard-Christensen, Maj

2010 When Utopia Fails. Political Dreams and Imaginaries of Democracy in TimorLeste. Ph.d.-afhandling. Aarhus Universitet.

Paley, Julia

2008 Democracy. Anthropological Approaches. Santa Fe: School for Advanced Research.

Paris, Roland

2004 At War's End: Building Peace After Civil Conflict. Cambridge: University of Cambridge Press.

Pitts, Jennifer

2006 A Turn to Empire: The Rise of Imperialism in Britain and France. Princeton:

Princeton University Press.

Rose, Nikolas

1999 Powers of Freedom. Reframing Political Thought. Cambridge: Cambridge University Press.

Salkever, Stephen

2009 Reading Aristotle's Nicomachean Ethics and Politics as a Single Course of

Lectures: Rhetoric, Politics, and Philosophy. I: S. Salkever (ed.): The Cambridge

Companion to Ancient Greek Political Thought. Cambridge: Cambridge

University Press.

Sanger, David

2010 A Test for the Meaning of Victory in Afghanistan. New York Times 13. februar. http://www.nytimes.com/2010/02/14/weekinreview/14sanger.html.

Schumpeter, Joseph Alois

1947 Capitalism, Socialism, and Democracy. New York: Harper \& Brothers.

Tilly, Charles

2007 Democracy. Cambridge: Cambridge University Press.

Zeeuw, Jeroen \& Krishna Kumar

2006 Promoting Democracy in Postconflict Societies. Boulder: Lynne Rienner

Publishers. 


\section{EKSPERIMENTEL ANTROPOLOGI}

\section{ANDREAS ROEPSTORFF}

Kære kolleger, venner og familie

Det er en stor glæde at stå her i dag, og det er også noget skræmmende. Skræmmende, fordi oplægget vel er at skulle sige noget væsentligt, på vegne af Faget og Traditionen og forankret i Personen. Det er en af den slags opgaver, hvor frygten for det hvide papir, den blanke skærm og det fyldte rum her i dag, den 21.1. kl. 14, kan virke mere end knugende, nærmest dræbende.

Og nu, hvor jeg står her, føler jeg mig kun rede til at tale med små bogstaver, men jeg har udfordret mig selv til at tale om Eksperimentel Antropologi: Må ritualet begynde.

Intet er, som det var i gamle dage. Dengang medførte et professorat en stol, man kunne sidde på resten af livet og derfra dominere felten og feltet omkring sig. Forleden dag kom en gammel bekendt op til mig og ønskede mig tillykke med ,emsoen“. Jeg fattede ikke, hvad han mente, og han måtte gentage det et par gange, før jeg forstod akronymet: MSO som i professor Med Scerlige Opgaver. Det dækker over en vis midlertidighed, en brændende platform snarere end en stol. Som der så prosaisk står i udnævnelsesbrevet: Efter fem år går du tilbage til din oprindelige stilling uden yderligere varsel. I mit tilfælde er „emsoen“ oven i købet udspændt mellem to brændende platforme, en her og en på den mere hårde side af ,kognitions-, kommunikations- og kulturfeltet“, derovre, hvor man måler på alt mellem himmel og jord.

Men hvor det ikke er godt at sidde mellem to stole, så er det måske ikke så skidt at kunne hoppe lidt frem og tilbage mellem to brændende platforme ...

Jeg har valgt i dag at koncentrere mig om den ene af platformene, en undersøgelse af, hvordan man kan begrebsliggøre et antropologisk mellemværende med det eksperimentelle. Diskussionen af, hvilke eksperimentelle resultater dette hidtil har været med til at producere, er en nært beslægtet historie, men detaljerne i det må vente til en anden dag. 
Der kan gives mindst tre betydninger af eksperimentel antropologi.

1) Det kan handle om en eksperimenteren med den antropologiske form og metode. Det er en undersøgelse af nye måder at arbejde på, at tilpasse sig den virkelighed, arbejdet udfolder sig i, og forhåbentligt følsomt at indoptage og afprøve de debatter, der rører sig i tiden. Inspireret af George Marcus vil jeg kalde det eksperiment som cestetik.

2) Eksperimentel antropologi kan forstås som en særlig form for praksis, der bekender sig til eksperimentet, og som tager eksperimentet som en måde at undersøge det antropologiske på. På samme måde som visuel antropologi ikke blot handler om at forstå det visuelle, men om at benytte sig af visualitet, film, billeder, collager, montager som måder at bedrive et antropologisk virke på, kan eksperimentet forstås som en del af en faglig praksis. Med andre ord, vi kan tale om eksperiment som metode.

3) Socialantropologi, fysisk antropologi eller kulturantropologi forsøger at forstå aspekter af det menneskelige med reference til det sociale, det kulturelle eller det fysiske for i sidste ende at forstå det, man med en lidt gammelt klingende term kunne kalde „den menneskelige natur“. På samme måde kan eksperimentel antropologi forstås som en analyse af det menneskelige med reference til det eksperimentelle og eksperimenterende for i sidste ende at forstå det eksperimentelles natur. I denne betydning bliver der tale om eksperiment som objekt.

Jeg mener, at alle tre betydninger af „eksperimentel antropologi“ er nyttige strømpile, og at de i praksis, i alt fald i min videnskabelige praksis, kan være tæt sammenvævede med hinanden. Jeg vil argumentere for, at det måske netop er i en konjunktion, at de kan fungere som en overskrift for en antropologisk undersøgelse, der kan have mere end en partikulær interesse. Jeg tror, at måden, hvorpå disse tre betydninger af eksperimentel antropologi kan bringes i kontakt med hinanden, måske har noget fornuftigt at sige om, hvori det ,antropologiske“, det menneskelige, hvad vi nu skal kalde det af store ord, består. Hvordan disse tre betydninger kan kombineres, vender vi tilbage til hen mod slutningen af dette oplæg.

\section{Eksperimentel antropologi 1: Eksperimentet som æstetik for praksis}

Ideen om, at den antropologiske form i sig selv er noget, der kan arbejdes med, står eksemplarisk som undertekst på George Marcus' og Michael Fischers banebrydende værk Anthropology as Cultural Critique. An experimental moment in the human sciences (Marcus \& Fischer 1986). Denne forståelse af antropologien som et eksperimenterende projekt, i form og indhold, kan følges i Marcus' ud- 
vikling gennem 90'erne eksemplificeret ved Late Editions-serien som han redigerede på Chicago University Press. På godt og ondt afprøvede den grænserne for antropologien som metode, som forskningsfelt og som måde at rapportere på. I denne tradition ligger der en bekenden sig til antropologien som en art avantgardeeksperimenteren med form, indhold, stil, repræsentation og en insisteren på, at dette er en underliggende pointe i det antropologiske projekt.

I de senere år har Marcus produktivt vendt denne undersøgelse indad mod en række meget frugtbare refleksioner over, hvordan antropologi kan og måske skal undervises. Her tegner der sig et billede af, at antropologiens konstant fluktuerende videnskabelige praksis kan stabiliseres via en insisteren på betydningen af det klassiske „første feltarbejde“ med en inspiration af den malinowskiske trope „,imagine yourself on a beach“ som et centralt tema. Ideen om, at man kan rejse til en isoleret $\varnothing$ og slå sit telt op blandt de vilde og skrive om dem ved observerende at deltage i deres liv, eller måske rettere deltagende observere deres liv, er en myteomspundet illusion, men, hævder Marcus tilsyneladende paradoksalt, alligevel er det en væsentlig del af antropologien (Marcus 2008). Vi vender tilbage til dette paradigmatiske „første feltarbejde“ igen i slutningen af dette foredrag.

Denne diskussion er videreført i Marcus' seneste artikel „Contemporary Fieldwork Aesthetics in Art and Anthropology: Experiments in collaboration and intervention" (Marcus 2010). Titlens fire nøgleord tegner her en relevant kvadrant for en nutidig antropologisk forskningspraksis. „Participant observation“ er blevet til „collaboration and intervention“, og ,,aesthetics and experiments" tegner konturerne af en bestemt forskningstilgang, hvor, som Marcus så prægnant formulerer det, ,the clichéd participant observation of traditional ethnography for the archive ... is replaced by an aesthetic of collaborative knowledge projects of uncertain closure" (op.cit.275).

Det er en interessant vej, Marcus tager frem mod eksperimentet. Via den Derrida-inspirerede tyske biolog og videnskabsteoretiker Jörg Rheinberger (1997) rekonstruerer han det videnskabelige eksperiment som en fundamental usikker og ontologisk meget kompliceret størrelse. „Eksperimentelle systemer“ er systemer til manipulation af materien, der giver ukendte svar på spørgsmål, som eksperimentatoren endnu ikke klart kan stille.

Det er en analyse, der tilsyneladende smukt matcher mine egne felterfaringer fra laboratorier. Eksperimenter er skrøbelige, usikre og komplicerede at fastholde. Mens de foregår, kan de gå galt på rigtig mange måder. Selv når man har fået produceret den form for orden, som eksperimentet ideelt lægger op til, er der notorisk modstand på spil (Roepstorff 2003c). At forstå og navigere i forhold til denne usikkerhed synes at være en central del af en eksperimentel skoling (Roepstorff 2007). „Først når eksperimentet er færdiganalyseret, ved man, hvordan det burde 
have været designet.“ Sådan siger en af mine nøgleinformanter, centrale samarbejdspartnere og hjernevidenskabelige mentorer igen og igen, når endnu et forsøg, som vi troede var designet til at give den endelige løsning på de store problemer, viser sig igen at være underligt uafklaret og ufortolkeligt på interessante, men grundlæggende trælse måder ...

Hvis det videnskabelige eksperiment er en sådan systematisk afprøven af fundamentale usikkerheder (foreslår Marcus (2010)), så er der en oplagt kobling til det, Nicolas Bourriaud (1998) kaldte den relationelle æstetik. Det drejer sig om undersøgelse, ikke af Værket med stort V, men af relationen mellem værk og betragter. Dette forhold bliver selve kunstværket, i sig selv uforudsigeligt og irreducerbart til værket selv, men dog ideelt struktureret på en sådan måde, at agens og intentionalitet ikke udfolder sig ganske tilfældigt. Dermed bliver, i Marcus' optik fra sidste år, vejen fra den moderne æstetiske praksis til den videnskabelige eksperimentelle praksis meget, meget kort. Det er i denne konjunktion, at antropologien kan finde et nyt hjem, hvor temporært det end måtte være, på en måde som en naturlig udvikling fra den inspiration fra de æstetiske praksisser og analyser, som i første omgang inspirerede, da postmodernismen ramte antropologien (Clifford \& Marcus 1986). I Marcus' klassiske, kryptiske formulering bliver konklusionen en ny konceptuel metafor for det etnografiske arbejde:

experiment as the ground of compensating aesthetics for the refunctioning of the Malinowskian scene of encounter toward a viable idea of multi-sitedness or nonsite specific fieldwork (Marcus 2010:274).

Sammen med ændringen i selve feltarbejdet bliver også både teksten og de andre anderledes, feltarbejdet er på en måde det samme som altid, men dog alligevel forskelligt, fordi det indfoldes i en anden fortolkningsramme. I Marcus' bud på, „hvor kort et feltarbejde kan være“, bliver det fortolket med en designstudiemetafor for forskningsprocessen, hvor samarbejdet om projektet bliver et normativt princip, og receptionen af feltarbejdet, både i det antropologiske miljø og i forhold til samarbejdspartnerne, bliver en central del af det (Marcus 2008). Hvis den antropologiske tekst om felten ikke længere kan fremstå autoritativ i sig selv, men blot skriver sig ind i forhold til tekster, der skrives i den felt, der beskrives, så er der behov for at forstå nogle nye modaliteter. Samarbejdet bliver centralt, og den viden, etnografien producerer, får som primær funktion mediering og intervenering. I alt fald hvis vi skal tro Marcus. Og det kan vi godt lidt endnu ...

Jeg har hermed påkaldt mig Marcus til at sige, at i mindst én forstand kan der godt argumenteres for, at det at tænke på antropologien som et eksperiment og at tænke eksperimentelt om en forskningspraksis i virkeligheden er udtryk for en state-of-the-art-metodisk refleksion. Den må altså ikke på nogen måde for- 
veksles med en naiv og ukritisk tilbagevenden til den positivistiske metode, vi alle har fået foragt for ind med den faglige modermælk eller andre metaforiske generationelle kropsvæsker.

Det er selvfølgelig et figenblad. Men det er et meget nyttigt figenblad, fordi det giver en slags licens til at gå ud at gøre det, man alligevel gør, men nu med den faglige sikkerhed, der ligger i en faderlig autorisation. Han har gjort præcist det før, Marcus, da han satte ordet „multi-sited fieldwork“ i spil i diskussionen af, hvordan man studerer globaliserede systemer (Marcus 1995). Pludselig blev det, der føltes rigtigt, men var umuligt i en klassisk ømetafor og -topologi, enormt meget flerstedsfeltarbejdsagtigt, forhåbentligt på den fede måde ...

Uden sammenligning i øvrigt er det et lidt tilsvarende tilbud om et figenblad, som Bruno Latour lancerede med ideen om aktør-netværk-teorien, som ikke er om aktører, ikke handler om netværk og ikke er en teori, men alligevel giver en lov til blot at forfølge relationer uden at bekymre sig alt for meget om, hvad de er (Latour 1997). Men det er en anden historie, som vi ikke skal forfølge nu (Roepstorff 1999).

Som alle andre figenblade kan man ikke være sikker på, om de ikke ved at dække det tilsyneladende væsentlige blot flytter blikket et andet sted hen. Godt nok får vi med Marcus' hjælp opløst den klassiske dikotomi om „os og dem“, om fremmedheden som absolut andethed, den kategoriske adskillelse. Vi får skabt en platform, hvor den intervenerende, samarbejdende rolle er blevet ikke blot en mulighed, men næsten et imperativ. Den rolle er dog også problematisk, som godt indfanget i den nærliggende danske metafor for dette, den antropologiske kollaboratør. Men lad os for nu stille os tilfreds med det figenblad, som Marcus har udstyret os med, og tage et skridt ind i den eksperimentelle felt ...

\section{Eksperiment som metode}

Der er ikke meget nyt under solen og heller ikke ideen om, at antropologien kan arbejde eksperimentelt. En af fagets „founding fathers“ var tysk-amerikaneren Franz Boas, der oprindeligt var uddannet i fysik og psykofysik. Han bedrev en række studier, som absolut befandt sig i det eksperimentelle felt, men på yderst interessant vis, eksempelvis i en kort artikel fra On Alternating Sounds (Boas 1889). I slutningen af det 19. århundrede var der i de dengang nye discipliner antropologi og arkæologi en vis besættelse om at finde ud af, hvordan ,arv“ og „miljø“ relaterede sig til hinanden, og til at forstå denne relation i et evolutionært perspektiv (Brinton 1898). Heller ikke her er der meget nyt under solen. Udviklingen og differentieringen af verdens talte sprog blev her set som en central arena for forståelsen af menneskehedens evolution. 
Et af problemerne med at bruge forskelle i sprog til at kortlægge udviklingen var identifikationen af det, der blev kendt som ,alternating sounds“, eller med en fordanskning, de foranderlige lyde (ibid.). En række af de lingvister, der i Nordog Sydamerika forsøgte at kortlægge de nyligt opdagede indfødte sprog, kom tilbage og fortalte, at de indfødte ikke kunne fastholde udtalen af ord fra gang til gang. Der manglede fonetisk konstans, eller som en af de forvirrede forskere, dr. Behrendt, der arbejdede med chapanecerne, udtrykte det: „No other language has left me in doubt as this one. The same person pronounces the same word differently, and when his attention is called to it, will insist that it is the same." En anden forsker, Father Montoya, beskrev hos guaranierne, at „there is in this language a constant changing of letters for which no sufficient rules can be given" (i Brinton 1888). Dette fik Daniel G. Brinton til at konkludere i en indflydelsesrig artikel: „The phonetic elements of primitive speech [as deduced through the native American languages] probably had no fixedness" (Brinton 1888:218).

Så træder Franz Boas ind på scenen. Han var opdateret med de seneste udviklinger i den helmholtzske tradition for psykofysik og vidste alt om, hvordan sansediskrimination foregik i forskellige modaliteter. Det brugte han til at argumentere for, at

new sensation is apperceived by means of similar sensations that form part of our knowledge ... [not that] such sensations are not recognized in their individuality, but they are classified according to their similarity, and the classifications are made according to known sensations (Boas 1889:50).

Når dette princip blev overført på fonemdiskrimination, betød det, at de fonetiske klassifikationer, man kendte fra ens velkendte sprog, ville påvirke, hvordan sproglyde i et nyt sprog blev opfattet. Udstyret med den hypotese undersøgte Boas transskriptioner af de mange inuitdialekter, der var ved at blive kortlagt over hele Arktis. Dette viste for det første, at transskriptionen var påvirket af lingvistens nationalitet, og at selv den samme lytter (Boas selv) ved forskellige lejligheder ville stave det samme ord på forskellig vis. Endnu mere markant var det, at disse stavemåder ændrede sig over tid, efterhånden som observatøren blev stadig bedre til at fange de lyde i det nye sprog, som ikke fandtes i det gamle. Dette fik Boas til at vende argumentet på hovedet:

I think ... it is clear that all such misspellings are due to wrong apperception, which is due to the phonetic system of our native language. For this reason, I maintain, that there is no such phenomenon as synthetic or alternating sounds, and that their occurrence is in no way a sign of primitiveness of the speech in which they are said to occur; that alternating sounds are in reality alternating apperceptions of one and the same sounds (op.cit.52). 
Det handlede altså ikke om, at de indfødte ikke var i stand til at producere lyde på samme måde fra gang til gang, men om, at den observatør, der ikke kendte sproget i forvejen, simpelthen hørte den samme lyd forskelligt fra gang til gang. Boas gik systematisk i gang med at undersøge to implikationer af dette. 1) Hvorvidt „forskellige“ lyde, der alle ligner en ,kendt" lyd, vil blive hørt ens, selv om de er forskellige (lydblindhed med en analogi til farveblindhed). 2) Hvorvidt indfødte, der talte et sprog med foranderlige lyde, ville opfatte lyde i sprog, der blev anset som „stabile“ (tysk eller engelsk), som foranderlige. Baseret på de enkeltforsøgspersonstudier, der talte som videnskab for 100 år siden, fandt han evidens for begge hypoteser. Han kunne derfor konkludere, at foranderlig apperception kunne være en mekanisme, der både lå under de tilsyneladende adskilte fænomener „foranderlige lyde“" og „lydblindhed“.

Der er en moderne krølle på dette i det måske bedste studie af ,kulturelle forskelle" $\mathrm{i}$ hjernen. Kort efter murens fald undersøgte den finske kognitive neurofysiolog Risto Näätänen sammen med en række finske og estiske kolleger, hvordan finner og estere reagerede på de samme fysiske lyde. De udnyttede, at selv om finsk og estisk er tæt beslægtede sprog, er der i estisk udtale en vokallyd, /õ/, som ikke findes på finsk. I en rent akustisk analyse ligger denne lyd nogenlunde midt mellem de to vokaler, /o/ og /ö/, der findes på begge sprog. Forsøget gik nu ud på at udsætte estiske og finske forsøgspersoner for en lang række af disse velkendte lyde, og så indimellem præsentere dem for nogle afvigende lyde, blandt andet vokalen /ö/, der findes i begge sprog, den estiske vokal /õ/ eller en konstrueret lyd [/e/ö], der i begge sprog faldt uden for de fonetiske kategorier. Imens målte man EEG- og MEG-signaler. Det er måder at registrere den elektriske og deraf afledte magnetiske aktivitet $\mathrm{i}$ hjernen på. Formålet var at identificere hver lyds „mismatch negativity“ (MMN), et mål for, hvor overraskende et stimuli er.

Forsøget viste, at når esterne blev præsenteret for et uventet /õ/, var der en større MMN, end når de blev præsenteret for den konstruerede [/e/ö]-lyd, der ikke faldt sammen med en vokalkategori. For finnerne var der (i alt fald målt med MEG) ikke forskel på MMN-størrelsen til disse to lyde (Näätänen et al. 1997). Forsøget illustrerede med andre ord, men formodentlig uden at være klar over det, Boas' pointe om, at „lydblindhed“ kan hænge sammen med, hvilke sproglige distinktioner man er vant til at opfatte. Dette er væsentligt, også i forhold til en neurokognitiv diskussion, fordi det meget konkret viser forskellen på, om lydklassifikation opfattes ,inde fra et klassifikationssystem“ eller „udefra“. En tilsvarende tilgang har vi således benyttet $i$ en undersøgelse af forskelle mellem musikere og ikke-reaktioner i reaktioner til rytmer (Vuust, Ostergaard, Pallesen, Bailey \& Roepstorff 2009). 
Boas argumenterede for, at når man opfatter lyde, så gør man det baseret på de klassifikationsmønstre, man allerede kender. Der er med et lidt opdateret vokabular tale om, at strukturer i en allerede etableret praksis påvirker den måde, lyde høres på. Der er både en inderside og en yderside til dette. Kender man sproget, er man indenfor, og så kan lydene falde ned i de kategorier, som taleren udtrykker. Kender man ikke sproget, er man udenfor og kan gå glip af en vigtig distinktion eller, som i de vekslende lyde, høre to lyde som forskellige, selv om de skulle have været opfattet ens. Boas generaliserer denne opfattelse til at være en mere almen model for, hvordan „kultur" fungerer. Jeg har sammen med mine kolleger i Berlin Jörg Niewöhner og Stefan Beck argumenteret for, at dette kan være én illustration af betydningen af mønstre i praksis, og at en sådan ,patterned practice"-tilgang kan være en måde at bringe klassiske antropologiske indsigter i spil i forhold til igangværende diskussioner i kognitionsforskningen (Roepstorff, Niewohner \& Beck 2010). Jeg vil ikke i dag forfølge dette spor videre, men vil i stedet fastholde et andet moment i Boas' analyse, der demonstrerer et af kendetegnene ved en eksperimentel tilgang. På en og samme tid sætter det noget $\mathrm{i}$ spil både i forhold til materialet, der bliver undersøgt, og lige så vel i forhold til de forestillinger, der informerer fortolkningen af det. Bliver man opmærksom på det og følsom over for det, som Boas så eksemplarisk demonstrerede, ligger der i dette en art „eksperimentets dobbeltnatur“: Det kan pege både udad mod verden og indad mod en refleksiv forståelse af traditionen.

Uden sammenligning i øvrigt var det en tilsvarende undren, der prægede min første involvering i det funktionelle skanningsmiljø. Her var forestillingen om den simple subjekt-objekt-relation pakket ind i meget konkrete menneskelige interaktioner, forventninger, forudforståelser og synkronisering af handlinger. Med andre ord: Resultatet af eksperimenterne præsenterede billeder af hjerner, der lyste op, som rene stimulus-respons-fænomener. Deltagelsen i eksperimenterne viste, at det kræver en frygtelig masse interaktion og forforståelse, en frygtelig masse „kultur“, at tegne et billede af mennesket som tilsyneladende ren natur (Roepstorff 2001a).

Jeg blev, efter jeg havde bedrevet feltarbejde i det neurokognitive miljø, spurgt, om jeg kunne tænke mig at arbejde med og for de folk, jeg tidligere havde studeret blandt, ved at være med til at etablere et kognitivt forskningsmiljø omkring Danmarks Grundforskningscenter for Funktionel Integrativ Neuroforskning (CFIN). Min udmelding var, at det ville jeg gerne, og at min egen hovedinteresse var at sætte netop dette på dagsordenen: en eksperimentel undersøgelse af, hvad der sker i interaktioner, og hvad der muliggør interaktionen som et emergerende fænomen. Gerne både i laboratoriet og i felten, gerne både på fysiologisk, adfærdsmæssigt og neuralt plan, gerne med anvendelse af hele svineriet af maski- 
ner og matematiske modeller, og jeg skal komme efter dig af teknologi og teknologiske processer, gerne i forhold til alle hånde kliniske patientgrupper.

Godt støttet af grundforskningsfonden har jeg fået lov til at arbejde med implementeringen af dette, de sidste år hovedsageligt som koordinator for The Interacting Minds Group (www.interacting-minds.net). De undersøgelser, der er lavet, har kun kunnet lade sig gøre i kraft af samarbejder med en række fantastiske kolleger, som på visse planer har haft parallelle interesser og har haft de kompetencer, der skal til for at kunne gennemføre det til de standarder, den slags nu kræver.

Fundene er interessante, men det ligger uden for dagens foredrag at gå i detaljer med dem. En udfordring har været at sætte interaktion som emergerende fænomen på dagsordenen (Bahrami 2010; Konvalinka 2010), en anden at lade social og kulturel kontekst være den eksperimentelle variabel, der sætter kontrasterne op (Cambell-Meiklejohn, Bach, Roepstorff, Dolan \& Frith 2010; Schjoedt, Stoedkilde-Jorgensen, Geert \& Roepstorff 2011; Sip et al. 2010). Det tegner måske konturerne af en måde, hvorpå antropologien, og antropologer, kan indgå i den debat om „det menneskelige“, som engang var central i antropologien, men p.t. er ved at blive overtaget af en neural og kognitiv implementering, og som nogle gange forekommer et antropologisk perspektiv mere reduktionistisk, end godt er (Roepstorff 2011; Roepstorff et al. 2010).

Selv om interacting-minds-projektet ikke var eksplicit konstrueret med de marcuske begreber for det nutidige intervenerende og medierende antropologiske arbejde, kan det, tror jeg, godt dækkes af det, vi kunne kalde det marcuske figenblad. I alt passer hans beskrivelse af an aesthetic of collaborative knowledge projects of uncertain closure meget bedre til min arbejdsproces i det felt end den traditionelle etnografis deltagerobservation ... Men den mere detaljerede udfoldning af dette kræver nok en version af den klassiske etnografiske tilbagetrækning fra felten.

\section{Eksperiment som objekt}

Hvad er eksperimentet for en størrelse? Vi ved, at de kan gøre magiske ting: transformere kultur til natur (Roepstorff 2002), fjerne agens og fri vilje fra folk (Roepstorff \& Frith 2004) og i en større målestok etablere og stabilisere nye verdener (Shapin \& Shaffer 1985). Om man blot nævner nogle af kernebegreberne - gentagelse, synkronisering, orkestrering, forskubbelse af agens, transformation - tegner det også konturerne af ritualet, en anden menneskelig praksis, antropologer har vendt og drejet siden fagets fødsel. Som struktureret praksis er der mere end nogle få ligheder mellem de to former, men hvor ritualets antropologi 
er foldet godt og grundigt ud, så ved vi endnu meget lidt om eksperimentets antropologi.

En af måderne, mine kolleger i interacting minds-gruppen har forfulgt dette på, har været at tage eksperimenterne til felten. I felten står ritualer som et af de scenarier, der byder sig til som en mulighed for at arbejde eksperimentelt. Et af forsøgene foldede sig ud omkring et årligt tilbagevendende ritual i en lille spansk landsby, hvor nogle af indbyggerne på årets længste dag går på glødende kul, mens de bærer folk på skuldrene, omgivet af tusindvis af tilskuere, lokale såvel som turister. Dimitris Xygalatas, Ivana Konvalinka med flere tog eksperimentelt del i dette ritual, blandt andet ved at udstyre såvel deltagere i ritualet som observatører med enkle pulsmålere for at undersøge, i hvilket omfang ildvandrernes fysiologiske ophidselse var delt af dem, der så på. I analysen af dette måtte vi vidt omkring, blandt andet til folk, der havde ekspertise i forståelsen af komplekse dynamiske systemer. Vi venter i disse dage på svar på, om studiet bliver accepteret der, hvor vi gerne vil have det ud (Konvalinka et al., under review), men det billede, der tegner sig, synes ret klart. Der er, ikke overraskende, en stor fysiologisk effekt af, at man går på glødende kul. Hos dem, der ser på, ser vi en forskel mellem dem, der „blot“ er tilskuere“, og så dem, der har en tilknytning til de ildvandrende. Effekten bliver blandt andet fanget ved hjælp af obskure mål for strukturen i pulsmålingerne, laminarity, \% DETerminacy, MAXline, entropy, der vokser ud af komplicerede Cross Requrency Plots.

Disse analyser fungerer som evidensankre, der, hvis artiklen bliver accepteret, tillader et bestemt narrativ i en bestemt diskurs og bringer Durkheims gamle idé om collective effervescence i spil i forhold til fysiologi og komplekse systemer. Men om artiklen bliver publiceret eller ej, ligger bag dette argument et forunderligt forhold, som er i både eksperimentets og ritualets natur. Begge trækker på en mulighed for at sætte bestemte rammer for interaktion. De etablerer særlige rum, hvor mennesker på bestemte måder agerer med hinanden, med de andre og med den fysiske verden, og delvis i kraft af den delvist emergerende organisering kan de blive transformeret i processen. Disse transformationer har også en meget væsentlig eksperientiel komponent. Meget konkret sådan, at den gruppe forskere, der tog af sted for at prøve at måle, hvad ritualet gør, så vidt jeg kan se, også selv kom tilbage transformerede, både af ritualet og eksperimentet. De kom hjem med en anden fornemmelse af, hvad det vil sige at lave eksperimenter, og hvad der sker i menneskelig interaktion.

Der ligger, tror jeg, et meget stort og uopdyrket felt $i$ at undersøge dette spændingsfelt mellem eksperimentet og ritualet refleksivt og eksplicit gøre det andre steder end i den strengt kontrollerede virkelighed, som det fysiske laboratorium er. Det handler ikke blot om at tage laboratoriet til felten i en meget konkret for- 
stand (Henrich et al. 2005). Det handler også om at arbejde med og undersøge, hvad der sker, når man sætter den mærkelige ramme, som eksperimentet er. Der er noget med at sætte noget i spil, som nok har et intenderet formål, men som reelt ikke kan styres i alle detaljer. Det etablerer en arena, hvori modstand kan blive etableret, både fra ,de andre“ og fra materien. Både ritualer og eksperimenter kan gå galt, og i en vis forstand skal de kunne gå galt. Dermed er det på en og samme tid en bekræftelse på det velkendte og en mulig og potentielt produktiv udfordring af etablerede strukturer, hvad enten disse er sociale relationer eller kendsgerninger. Det er en udfordring af såvel de sociale som epistemiske modstandspunkter (Fleck 1979; Roepstorff 2003c). Min fornemmelse er, at der i den antropologiske analyse af eksperimenter kan hentes inspiration fra rituallitteraturen, og at det kan give en forståelse af, hvorfor centrale elementer som agens, oplevelse og erfaring synes at blive ikke-eksisterende og meget konkret usynlige i den herskende kognitive eksperimentelle litteratur (Jack \& Roepstorff 2002; Roepstorff 2003b; Roepstorff \& Frith 2004; Roepstorff \& Jack 2004). Som man kan se af den e-mail-trialog, som Nils Bubandt, Rane Willerslev og jeg har udfoldet op til i dag, er dette også et område, som tilbyder indlysende koblinger til andre antropologiske arbejdsdomæner som for eksempel den museale praksis (Bubandt, Roepstorff \& Willerslev 2011).

\section{Afslutning}

Under mit eget arbejde de sidste år har der været en kraftig opblødning eller omdefinering af feltarbejderrollen, i „min“ felt som i andre felter. Det giver ikke mening at tale om en malinowskisk dem-os-dikotomi. I tidligere arbejder har jeg skrevet om det som en ,insiders and outsider unite“-tilgang (Roepstorff 2001b), men det er, har erfaringen lært mig, nok både forsimplet og naivt. Der er tale om forskellige projekter og perspektiver, hvor det mere handler om at identificere grænseflader og intermediære fællesskaber end global enhed og enighed (Roepstorff 2003d).

Uden at gå i detaljer med det her er en noget tilsvarende rolle for antropologen blevet foreslået af Matti Bunzl, som en neoboasiansisme, inspireret af Focault (Bunzl 2004, 2008). Fokus bliver her en undersøgelse af historicitet, hvor hverken feltarbejder eller "de lokale“ har en forud privilegeret indsigt for at forstå tidsligheden. Det åbner for antropologi som en historisk etnografi om secondary explanations, en Boas-term til at beskrive en rationalisering af habituel adfærd, hvis oprindelse er forsvundet $\mathrm{i}$ traditionen, men i sig selv er ladet med emotionel værd. Det er ikke et spor, jeg her kan forfølge yderligere, men det er interessant, at Boas-inspirerede tilgange stikker hovedet frem hist og her, 
og det er muligt, at de i en nyfortolkning kan løse nogle problemer, faget ellers har fået skabt for sig selv.

Jeg har forsøgt at argumentere for, at et af de steder, antropologer i dag kan hente inspiration, er i et engagement med det eksperimentelle, ikke i en snæver forstand, men i mindst de tre betydninger, der her er skitseret. Min fornemmelse er, at en mulig kobling mellem disse tre former for ,eksperimentel antropologi“ tager udgangspunkt i et spørgsmål om skala. En insisteren på, at der i antropo-logi ligger en fastholdelse af det „,menneskelige som skala“, selv om undersøgelsen af, hvori dette menneskelige til enhver tid består, i sig selv er en del af skaleringen. Jeg tror, at der i fastholdelsen af dette ligger muligheden for at fastholde en antropologisk praksis som eksperimenterende $\mathrm{i}$ alle tre betydninger - som æstetik, som objekt og som metode.

Her kommer de epistemiske objekter ind, som via Rheinberger satte Marcus på sporet af det eksperimentelle, også i antropologien. I de nye fortællinger om mennesket, som p.t. kæmper om pladsen, er der en tendens til, at agensen udføres af sådanne epistemiske objekter. Dit gen eller dit meme gør „det“ og gør „dig“ til den, du er. Din mediale præfrontale kortex er underudviklet, og derfor har du det svært med dig selv, med de andre og med at tage ansvar. Din kultur eller din sociokulturelle status får dig til at gøre det, du gør. Hvis der er én lektie, som de etnografiske studier af disse epistemiske objekter har givet os, så er det, at deres eksistens i mange tilfælde, måske endda de fleste, er skrøbelig og tentativ, og at de er fastholdt af en række praksisser og teknologier (Latour 1999). Hvad er et gen? For ikke så mange år siden vidste vi det, der var noget med en promotorsekvens og noget, der kodede, og så noget ,junk“ ind imellem, der blot blev klippet ud. Men i dag er billedet ikke så klart. Det ikke-kodende dna, junket, er pludselig kommet på banen som en kandidat til agens, og dermed skrider også, hvad genet er (Biemont \& Vieira 2006; Willingham \& Gingeras 2006). På samme måde med hjerneområder. Hjerner findes, men hvor er det lige, grænsen går mellem V5 og V4, og hvor ligger STS? Eller på et felt tæettere på antropologien: Hvad er kultur? Og hvad betyder det, at denne tilskrives agens? Det er til tider som at se en ANT (Latour 2005; Law \& Hassard 1999) på syre løbet løbsk, nu ikke som videnskabelig model, men som emisk fortælling, og de samme videnskabelige traditioner, der havde problemer med, at en dør eller et sikkerhedsbælte kunne have agens (Latour 1992), tilskriver det tilsyneladende gerne usynlige objekter, hvis ontologiske status er noget tvivlsom.

Jeg nævnte tidligere, at Marcus med flerstedsfeltarbejdet havde lanceret et fagligt figenblad. Det har vist sig nyttigt, når man skal studere alle hånde mærkelige objekter og praksisser. I en faglig i praksis fungerer det lidt som 007's $l i$ cense to kill. Det er legitimt at lade forskningsprocessen selv påvirke, hvilken 
vej projektet går. Det er det, lyder påstanden, fordi man på den måde følger den skala, som empirien udfolder sig på. Det har åbnet verdenen på nye måder og for nye påtrængende perspektiver og analyser. Men som alle andre licenser er den givet under ansvar. Man skal, hvis man vil kalde sig antropolog, kunne komme tilbage og fortælle om det, oversætte ind i et fagligt fællesskab, som på en og samme tid er forestillet og meget, meget konkret. Nu vover jeg et øje, men i den oversættelsesproces er der noget omkring skala, som synes vigtigt. Det kan godt både handle om det mindste molekylære og de største globale super- og infrastrukturer. Men det skal også oversættes på en måde, der muliggør en resonans i et erfaringsrum, som er mere eller mindre kropsliggjort. Måske fordi den erfaring af at være et andet sted, med andre og med sin krop - hvad det nu end betyder og implicerer i en nutidig, medieret virkelighed - er den erfaring, som fagets udøvere deler? Det er i alt fald én måde at forstå George Marcus' centrale pointe om „vigtigheden af det første feltarbejde“ på.

Med Nils Bubandt redigerede jeg for nogle år siden en bog (Roepstorff, Bubandt \& Kull 2003), hvor vi argumenterede for, at forestillinger om kultur - og natur - på mærkelig vis ser ud til at komme til at handle om en mærkelig blanding af ontologi, epistemologi, etik og æstetik. Vi sagde, at det måske blev et spørgsmål om kosmologi (ibid.). Her bringer feltarbejdet tilsyneladende en vigtig og uomgængelig erfaring med sig, som vi som antropologer måske skal begynde at hviske til hinanden, for senere, måske, også at sige det i en større offentlighed: Mennesket findes. Eller rettere: Der findes mennesker! Det handler om eksistens, eller på fin ontologi: Der findes rent faktisk mennesker i verden, de kan både beskrives, erfare og handle, både være objekter og subjekter og agenter. Meget mere behøver vi måske ikke sige nu, men det trækker en masse med sig, også alt det andet kosmologiske: etik, epistemologi og æstetik (Roepstorff 2003a).

Dette er måske et passende sted at stoppe og måske passende gøre det med en performans:

Drej hovedet, se din sidemand eller -kvinde i øjnene og hvisk sagte, men dog hørbart:

Der findes mennesker!

\section{Tak}

Tilbage er kun at sige tak:

Til kolleger, venner, familie og konkurrenter for at komme i dag og for at være der hver dag.

Til mine forældre, der bragte mig frem og lærte mig alt det vigtigste, og til deres nye partnere, der har lært dem, og mig, en masse nyt. 
Til Karen, my partner i alle ordets betydninger, for det meste, men i særdeleshed også for at lære mig at kunne være i stue med mig selv og andre.

Til børnene, både jer, der er med i dag, og de, der ikke kunne komme, for konstant at sætte alt i perspektiv.

Fagligt som personligt er jeg en hjemmefødning, og jeg kan ikke påkalde mig en berømt antropologisk doktor Vater eller Mutter i udlandet, jeg er lokal, og jeg skylder en stor tak til Susanne Dybbroe, der først tog mig hjem og så sendte mig ud, til Poul Pedersen, som gang på gang har skubbet, på hvad der viste sig at være rette sted og tid, eksempelvis med ,alternating sounds“, og til Ton Otto, fordi han er Ton, både når han er her, og når han ikke er her.

Endelig i den mærkelige hybride felt en stor tak til Leif Østergaard og Albert Gjedde, der gav mig en chance og lærte mig en masse, til Chris og Uta Frith, både i deres roller af informanter, mentorer, forbilleder og kolleger for at åbne den kognitive forskning på rigtig mange planer, og til alle de andre, der gør det sjovt at udforske interacting minds.

\section{Litteratur}

Bahrami, Bahador, K. Olsen, P.E. Latham, G. Rees, A. Roepstorff \& C.D. Frith

2010 Optimally Interacting Minds. Science 329(5995):1081-5.

Biemont, Christian \& C. Vieira

2006 Genetics: Junk DNA as an Evolutionary Force. Nature 443(7111):521-4.

Boas, Franz

1889 On Alternating Sounds. American Anthropologist 2(1):47-54.

Bourriaud, Nicolas

1998 Relational Aesthetics. Paris: Les Presses du réel.

Brinton, Daniel G.

1888 The Language of Palæolithic Man. Proceedings of the American Philosophical Society 25(128):212-5.

1898 The Factors of Heredity and Environment in Man. American Anthropologist 11(9): 271-7.

Campbell-Meiklejohn, Daniel, D.R. Bach, A. Roepstorff, R.J. Dolan \& C.D. Frith

2010 How the Opinion of Others Affects our Valuation of Objects. Current Biology 20(13):1165-70.

Clifford, James \& George E. Marcus (eds.)

1986 Writing Culture. Berkeley: University of California Press.

Fleck, Ludwik

1979 Genesis and Development of a Scientific fact. Chicago: Chicago University Press. 
Henrich, Joseph, Robert Boyd, Samuel Bowles, Colin Camerer, E. Fehr, H. Gintis, R. McElreath, M. Alvard, A. Barr, J. Ensminger, N.S. Henrich, K. Hill, F. Gil-White, M. Gurven, F.W. Marlowe, J.Q. Patton \& D. Tracer

2005 "Economic man" in Cross-cultural Perspective: Behavioral Experiments in 15 Small-scale Societies. Behav Brain Sci 28(6):795-815; discussion 815-755.

Jack, Anthony Ian \& Andreas Roepstorff

2002 Introspection and Cognitive Brain Mapping: from Stimulus-Response to ScriptReport. Trends in Cognitive Sciences 6(8):333-9.

Konvalinka, Ivana, D. Xygalatas, J. Bulbulia, U. Schjødt, E-M. Jegindø, S. Wallot, G.V. Orden \& A. Roepstorff

under review Synchronized Arousal Between Performers and Related Spectators in a Firewalking Ritual. PNAS.

Latour, Bruno

1992 Where are the Missing Masses? The Sociology of a Few Mundane Artifacts. I: W. Bijker \& J. Law (eds.): Shaping Technology. Cambridge, MA: MIT Press.

1997 Om aktør-netværks-teori. Nogle få afklaringer og mere end nogle få forviklinger. Philosophia - Tidsskrift for filosofi 25(3-4):47-64.

1999 Pandora's Hope: Essays on the Reality of Science Studies. Cambridge, MA: Harvard University Press.

2005 Reassembling the Social: An Introduction to Actor-network-theory. Oxford, New York: Oxford University Press.

Law, John \& J. Hassard (eds.)

1999 Actor Network Theory and After. London: Blackwell Publishers.

Marcus, George E.

1995 Ethnography in/of the World System: The Emergence of Multi-sited Ethnography.

2008 How Short can Fieldwork be? Social Anthropology 15(3):353-7.

2010 Contemporary Fieldwork Aesthetics in Art and Anthropology: Experiments in Collaboration and Intervention. Visual Anthropology 23(4):263-77.

Marcus, George E. \& Michael M.J. Fischer

1986 Anthropology as Cultural Critique: An Experimental Moment in the Human Sciences. Chicago: University of Chicago Press.

Näätänen, Risto, A. Lehtokoski, M. Lennes, M. Cheour, M. Huotilainen, A. Iivonen, M. Vainio, P. Alku, R.J. Ilmoniemi, A. Luuk, J. Allik, J. Sinkkonen \& K. Alho

1997 Language-specific Phoneme Representations Revealed by Electric and Magnetic Brain Responses. Nature 385(6615):432-4.

Rheinberger, Hans-Jörg

1997 Towards a History of Epistemic Things. Stanford: Stanford University Press.

Roepstorff, Andreas

1999 Fra det tællelige til det fortællelige. Noter fra et feltarbejde blandt hjerneskannere og videnskabsfolk. I: M. Gullestad, C. Hasse, T. Otto, A. Roepstorff \& K.E. Spannow (eds.): Antropologiens muligheder og metoder i eget samfund. Århus: Dansk Etnografisk Forening.

2001a Brains in Scanners: An Umwelt of Cognitive Neurosicence. Semiotica 134(1/4): $747-65$

2001b Insiders and Outsiders Unite! Science and Science Studies in/of the 21. Century. I: K. Siune (ed.): Science Under Pressure. Aarhus: The Danish Institute for Studies in Research and Research Policy. 

Imaging Laboratory. FOLK, Journal of the Danish Ethnographic Society 44:14570 .

2003a Clashing Cosmologies. Contrasting Knowledges in the Greenlandic Fishery. I: A. Roepstorff, N. Bubandt \& K. Kull (eds.): Imagining Nature. Practices of Cosmology and Identity. Aarhus: Aarhus University Press.

2003b A Double Dissociation in Twentieth Century Psychology? Journal of Consciousness Studies 10(1):62-7.

2003c Laboratoriet. Stedet for erkendelse. I: K. Hastrup (red.): Ind i verden. En grundbog i antropologisk metode. København: Hans Reitzels Forlag.

2003d Outlining the Sandpit of Consciousness Studies: A Question of Foundations or of Style? Bulletin fra Forum for Antropologisk Psykologi 13:44-52.

2007 Navigating the Brainscape: When Knowing Becomes Seeing. I: C. Grasseni (ed.): Skilled Vision. Between Apprenticeship and Standards. Oxford: Berghahn Press.

2011 Culture: A Site of Relativist Energy in the Cognitive Sciences. Common Knowledge 17(1):37-41.

Roepstorff, Andreas \& Nils Bubandt

2003 Introduction: The Critique of Culture and the plurality of nature. I: A. Roepstorff, N. Bubandt \& K. Kull (eds.): Imagining Nature. Practices of cosmology and identity (pp. 9-30). Aarhus: Aarhus University Press.

Roepstorff, Andreas, Nils Bubandt \& K. Kull (eds.)

2003 Imagining Nature. Practices of Cosmology and Identity: Aarhus University Press.

Roepstorff, Andreas \& C.D. Frith

2004 What's at the Top in the Top-down Control of Action? Script-sharing and „Toptop" Control of Action in Cognitive Experiments. Psychological Research 68: 189-98.

Roepstorff, Andreas \& A.I. Jack

2004 Trust or Interaction? Editorial Introduction. Journal of Consciousness Studies 11(7-8):v-xxii.

Roepstorff, Andreas, J. Niewohner \& S. Beck

2010 Enculturing through Patterned Practices. Neural Networks 23:151-9.

Schjoedt, U., H. Stoedkilde-Jorgensen, A.W. Geert \& A. Roepstorff

2011 Highly Religious Participants Recruit Areas of Social Cognition in Personal Prayer. Social Cognitive and Affective Neuroscience 6(1):119-27.

Shapin, Steven \& Simon Shaffer

1985 Leviathan and the Air-pump: Hobbes, Boyle and the Experimental Life.

Princeton: Princeton University Press.

Sip, K.E., M. Lynge, M. Wallentin, W. McGregor, C.D. Frith \& A. Roepstorff

2010 The Production and Detection of Deception in an Interactive Game. Neuropsychologia 48(12):3619-26.

Vuust, Peter, L. Ostergaard, K.J. Pallesen, C. Bailey \& A. Roepstorff

2009 Predictive Coding of Music. Brain Responses to Rhythmic Incongruity. Cortex 45(1):80-92.

Willingham, A.T. \& T.R. Gingeras

2006 TUF Love for “Junk” DNA. Cell 125(7):1215-20. 


\title{
DET GUDDOMMELIGE BLIK
}

\author{
En analyse af „Den Dansende Troldmand“
}

\section{RANE WILLERSLEV}

Jeg er blevet fortalt, at der af en professortiltrædelsesforelæsning forventes et programskrift. Formålet er at skitsere det vidensfelt, som man er blevet gjort til professor inden for, og synliggøre, hvordan man agter at bidrage til dets udvikling. Det må i mit tilfælde siges at være noget af en udfordring! Mit professorat er givet inden for feltet „,vidensantropologi“, og man kan med rette spørge, om det ikke er urimeligt bredt. Antropologi handler helt grundlæggende set om viden: både forskellige kulturelle former for viden og skabelsen af antropologisk viden. I den forstand er vidensantropologi vel ikke andet end antropologi i al almindelighed. Hvis det vidensantropologiske felt skal give mening som noget i sig selv, må det dreje sig om grænserne for viden - det vil sige det, vi ikke kan vide noget om. Det er i hvert fald sådan, at jeg vælger at tolke feltet, om ikke andet $i$ anledning af dagens forelæsning.

Hvad kan vi så kalde det, som vi i sagens natur ikke kan vide noget om? Jeg vil kalde det for det ,guddommelige“. Og lad mig med det samme slå fast, at selv om min forståelse af det guddommelige på visse områder lapper ind over forestillingen om en absolut skabende Gud, så ligger der ikke fra min side noget religiøst $\mathrm{i}$ begrebet. For mig er det guddommelige synonym med det ,umulige“ (Caputo 2002:12), det vil sige det, der ikke kan begrebsliggøres, det, der kun er tænkbart som utænkeligt, det, der kun er nærværende gennem fravær.

Hvorfor dog forsøge at gøre noget, der ikke findes i konventionel forstand, endsige kan observeres eller beskrives etnografisk, til genstand for antropologisk analyse? Antropologi handler vel, som navnet antyder, om mennesket og ikke om det, der måtte overskride grænserne for det rent menneskelige?

Sådanne indvendinger vil afkræve en omfattende diskussion, som der ikke er plads til her. Jeg vil blot sige, at selv om det guddommelige ikke eksisterer i nogen konventionel fortand, så håber jeg i løbet af forelæsningen at overbevise jer om, at det netop er det, der giver det levede menneskeliv dets fylde. Ingen vi- 
denskabelig vej, der søger at forstå mennesket, kan derfor regne sig selv helt fri af spørgsmålet om det guddommelige. I den forstand bør antropologien, ligesom de øvrige humanvidenskaber, deltage i en slags „okkult" videnskab (ikke at forveksle med teologi), som indebærer viljen til at bryde med det tænkelige, med egne afgrænsende forestillinger, for at åbne sig mod det umuliges væsen. Det er her, vi finder humanvidenskabens største udfordring, men måske også dens største lidenskab: at tænke det, som ikke kan tænkes.

Nuvel. Dette med jagten på det guddommelige kan lyde som noget tågesnak. Så jeg må hellere skynde mig at sige, at det ikke vil stå alene. Samtidig med mit professorat på universitetet er jeg også afdelingsleder for De Etnografiske Samlinger på Moesgård Museum. Jeg vil derfor forholde mig - om end ad omveje - til det udfordrende i at vise noget, der ikke kan repræsenteres - nemlig det guddommelige. Sidst, men ikke mindst ligger det mig på sinde at styrke forskningssamarbejdet mellem antropologi og arkæologi, som jeg anser som to sider af samme fagområde. Min analyse tager derfor udgangspunkt $i$ et klassisk arkæologisk materiale, nemlig de berømte hulemalerier fra ældre stenalder.

\section{Den dansende troldmand}

Hulemalerierne i Sydeuropa udgør et imponerende vidnesbyrd om den pludselige eksplosion i kreativitet, der udfoldede sig, samtidig med at det anatomisk moderne menneske indfandt sig i Europa for omkring 30.000 år siden. Hulemalerierne er i virkeligheden de første etnografiske ,udstillinger", for de er blandt de tidligst kendte eksempler på, at mennesket forsøger at afbilde sin „modpart" - i dette tilfælde dyrene - $\mathrm{i}$ hvad der synes at være sammenhængende symbolske budskaber.

Det er først og fremmest byttedyr, der er afbildet, rensdyr, kronhjort, hest, bison og mammut, men der er også nogle få rovdyr - løve, bjørn og ulv. Dyrene er naturalistisk gengivet med detaljerede skildringer af øjne, horn og haler, men de virker samtidig typiseret med deres kraftfulde positur og overlæssede kroppe. De er givetvis tænkt som bytte, for flere af dem er aftegnet med pile i kroppen, og der er også fundet spor efter slag med stenredskaber på flere af dyreportrætterne.

Hvad gælder mennesket, er der så godt som ingen afbildninger. Vi finder dog en gådefuld figur, der har fået tilnavnet „Den Dansende Troldmand“. Variationer af figuren findes i flere af hulerne, men den fremstår særlig tydeligt i Sanctuaryhulen i Les Trois-Fréres. Figuren (se illustration) viser et hybridt væsen, der uden tvivl er hankøn. Han står sidelæns, som er han på vej til at tage et spring, mens han kaster et blik direkte ud på beskueren. Hver del af hans anatomi tilhører et dyrs: Han har kronhjortens gevir, ulvens ører, uglens øjne, løvens ansigt, rensdyrets 
skæg, bjørnens poter og vildhestens hale. Hans overordnede fremtoning er dog utvetydig menneskelig.

Den Dansende Troldmand, der er afbildet i hulens loft (ca. 3,5 meter over jorden), fremstår som midtpunktet mellem alle dyrene, der strækker sig i alle retninger omkring ham, ofte $i$ et kompliceret sammenspil af overlapninger. Figuren er da også blevet anset for at være selve nøglen til afkodningen af maleriernes betydning. Siden opdagelsen i 1870 'erne har figuren været genstand for en række tolkninger. Henri Breuil (1958) antog ham for at være en shaman i ceremoniel dragt på vej til at skifte skikkelse. Andre har foreslået, at figuren forestiller dyrenes ånd, der indeholder noget fra alle arter i sig (Gimbutas 1989:174-5; Vitebsky 1995:29). En mere fantasifuld tolkning foreslår, at figuren er et selvportræt af urtidskunstneren, der i narkotisk trance malede ikke kun dyrene, men også sig selv (Lewis-Williams 2002).

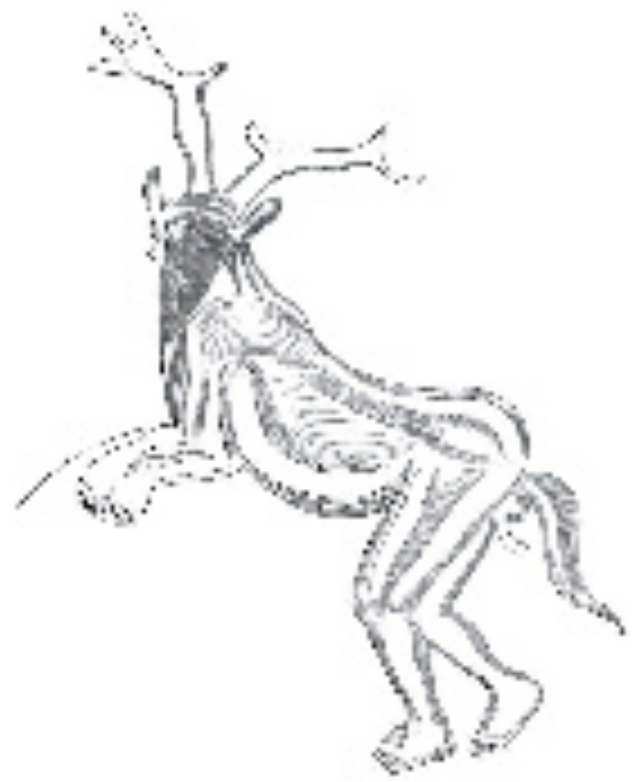

Den dansende troldmand. Illustration fra Clottes \& Lewis-Williams (1997).

Jeg vil i slutningen af forelæsningen føje endnu en tolkning til listen, nemlig den, at figuren er urtidsjægerens forsøg på at afbilde det guddommeliges blik. Da mulige fortolkninger er så godt som endeløse, gør jeg mig ingen forhåbninger om, at min egen skulle være mere sandfærdig, endsige mere verificerbar, end de øvrige. Men måske er netop det forhold, at figuren fremstår som evig gådefuld og derfor til stadighed inviterer os til nye kreative tolkninger, det bedste bevis for dets guddommelige afsæt. 
Lad jer ikke afskrække. Min indgang til emnet vil være ganske jordnær, nemlig en etnografisk kortlægning af, hvordan verdens nuværende jægerfolk, som på mange måder lever liv a la istidsjægerens, forholder sig til det guddommelige.

\section{Den animistiske højgud}

Lad mig begynde med at henlede opmærksomhed på en klassisk antropolog, der i dag stort set er gået i glemmebogen. Hans navn var Andrew Lang (1898), en folklorist og forfatter, der understregede, at teistiske forestillinger om eksistensen af en „højgud“ ikke kun forefindes i vores eget samfund, men også hos de mest „primitive“ folk. Selv blandt de australske aboriginere, som James Frazer anså for at være så primitive, at de ikke kendte til religion, men kun magi, var en „,højgud“ - den såkaldte ,alfader“- blevet påvist (Howitt 1884). Lang konkluderede derfor, at ,visse laverestående vilde er lige så monoteistiske som mange kristne" (i Stocking 1995:174).

I det nordøstlige Sibirien, hvor jeg har udført mine feltarbejder, blev der fundet etnografiske data, der også blev fortolket som bevis for en urmonoteisme, omkring samme tid som Lang fremlagde sin teori. Således beskrev de to legendariske etnografer Waldemar Jochelson og Waldemar Bogoras forestillinger om en højgud blandt Sibiriens angiveligt mest primitive indfødte, tjuktjerne og jukagirerne. Jukagirerne kaldte den Pon (Jochelson 1926:140, 235), hvilket betyder ,noget“, mens tjuktjerne (Bogoras 1904-9:314) kaldte den Va'irgin, som betyder ,noget eksisterende“.

Disse påstande om eksistensen af et gudelignende væsen blandt verdens mest primitive jægerfolk faldt ikke i god jord i datidens etablerede antropologiske miljø. E.B. Tylor (1958 [1871]) havde allerede foreslået, at religion udsprang af simple tanker om eksistensen af ,sjæle“, som så på et langt senere evolutionsstadie blev udviklet til en monoteisme. Det er derfor ikke overraskende, at Tylor (1891) på det kraftigste afviste Langs teori og hævdede, at de arkaiske guddomme var resultatet af kristendommens indflydelse og ikke et førkolonialt fænomen - et synspunkt, der for nylig har fået nyt liv af religionshistorikeren Jonathan Z. Smith (1982).

Jeg er dog af den opfattelse, at der er behov for en fornyet opmærksomhed på de afviste forestillinger om eksistensen af en urmonoteisme. Det betyder ikke, at jeg accepterer Langs teori om arkaiske højguder som parallel til den kristne Gud. Ud fra de oplysninger, som står til min rådighed, står det klart, at både Pon og Va'irgin ikke regnes for "guder" i vores forstand, men snarere er ligesom nuernes forestillinger om den „Kreative Ånd“, der ifølge E.E. Evans-Pritchard (1956:4-7) kendetegnes ved at være hinsides forståelse og kontakt, men som al- 
ligevel anses for at være giveren og opretholderen af alt liv. Jochelson skriver således om Pon, at „han er af en ubestemmelig og diffus karakter“ (1926:140). „Jukagirerne adresserer ham ikke i bønner og giver ham ikke offergaver ... [og deres] mytologi indeholder ingen henvisning ... til Pon“"(op.cit.235). Hvad angår tjuktjernes forestillinger om Va'irgin, er Bogoras (1904-9:314) endnu mere vag. Det står ikke klart, hvorvidt navnet henviser til en individuel guddom, eller om det snarere er et fællesnavn for hele gruppen af ånder. Imidlertid „hører [Va'irgin] ikke til dem, der ofres til" (ibid.), og han "spiller ingen aktiv rolle i mytologien“ (Jochelson 1908:26).

Beskrivelserne af disse guddommelige væsener som værende helt igennem udefinerbare, uden personlige eller andre konkrete træk og uden nogen kult knyttet til sig, blev fuldt ud bekræftet under mine egne feltstudier. Faktisk er både Pon og Va'irgin så godt som ukendte for nutidens jukagirere og tjuktjere. Hver gang jeg spurgte til dem, trak folk på skuldrene og sagde „hvem ved“, eller ,at de aldrig have hørt om noget sådant".

Vi må altså konkludere, at etnografisk set findes der så godt som ingen bevisførelse for Pons og Va'irgins eksistens. Der er ingen ofringer eller bønner rettet mod dem og ingen myter, der forklarer deres væren og handlinger. Faktisk kender befolkningerne i det store hele intet til deres navne. Og alligevel har jeg dem mistænkt for at være af afgørende betydning for det spørgsmål, som interesserer os her, nemlig de indfødtes forståelse af det guddommelige. For at vise dette er jeg dog nødt til at vende mig mod det klassiske antropologiske spørgsmål om „sjælen“, som Tylor påpegede er så centralt $\mathrm{i}$ animismen. Hvad er det animistiske sjælsbegreb for en størrelse, og hvordan, hvis overhovedet, er det forbundet med en urmonoteisme?

\section{Sjælen}

I både det nordlige (Rasmussen 1929; Hallowell 1960; Goldman 1975; Tanner 1979:136; Burnham 1992; Brightman 1993; Fienup-Riordan 1994) og sydlige Amerika (de Castro 1998; Descola 1986; Århem 1996; Vilaça 2005; Fausto 2007) lægger oprindelige folk vægt på ideen om, at dyr og ånder ser sig selv som mennesker: De lever i menneskelige samfund, gifter sig med hinanden og ernærer sig ved jagt. De samme tanker findes også blandt grupper af oprindelige folk i Sydøstasien (Howell 1989; Valeri 2000:305), Mongoliet (Pedersen, Empson \& Humphrey 2007:144) og det nordlige Sibirien (Jochelson 1926; Willerslev 2004, 2007, 2009; Willerslev \& Ulturgasheva i tryk). Lad mig kort citere Bogoras i forhold til tjuktjernes frygtede kannibalånder, ke'let (sing. ke'lE): 
Genstanden for deres jagter er udelukkende mennesket, som de normalt kalder 'en lille sæl' ... Efter at have fanget en, hugger de den i stykker, koger den i en kedel, og brødføder deres børn med den ... [Men] ke'let er ikke fritaget for angreb fra shamaner, der kan behandle dem på samme måde, som de behandler mennesker. Ke'let, på deres side, kalder shamanerne ke'let (Bogoras 1904-9:294-5).

Fænomenet, som vi har at gøre med her, er, hvad Eduardo Viveiros de Castro (1998) har betegnet ,,perspektivisme“. Det er en ontologi, ,ifølge hvilken verden er beboet af forskellige former for personer, menneskelige og ikke-menneskelige, der ser virkeligheden ud fra særskilte perspektiver“ (op.cit.469). Disse er dog ikke alternative perspektiver på den samme verden, men snarere en overførsel af samme perspektiv ind i forskellige virkeligheder. Ke'let ser verden på samme måde, som mennesker gør det, og opfører sig ligesom dem fra deres eget egoperspektiv. Dette skyldes, ifølge Viveiros de Castro, at både mennesker og ikkemennesker besidder den samme sjæl, og, som han skriver, „evnen til at antage et synspunkt er utvivlsomt et resultat af sjælen ... [og] eftersom sjælen formelt er identisk i alle arter, kan den kun se de samme ting alle steder"“ (op.cit.478).

Forskellen mellem perspektiver ligger derfor ikke i sjælen, men ipersonens særlige krop, med deres karakteristiske anlæg for handling og perception. Så mens ke'let går på jagt efter bytte på samme måde, som tjuktjerne går på jagt efter bytte, er det, som de to grupper ser som bytte, forskelligt og afhænger af deres respektive kroppe. Animisme og perspektivisme synes altså at være tæt forbundne fænomener (de Castro 1998:472-4), eller, som Morten Pedersen (2001:421) udtrykker det: „Perspektivisme er den stærkeste form for animisme.“ Tilsyneladende hviler perspektivismen på grundprincippet om, at personen består af en indre sjæl, skjult under en ydre krop. Hvor kroppen kan skiftes ud - de såkaldte „dyr-mennesketransformationer" - er sjælen konstant og identisk på tværs af artsforskelligheder. Dette er da også hovedbudskabet i de Castros teori om perspektivismen.

Der er dog noget uldent ved teoriens indbyggede dualisme. Her tænker jeg på den udbredte opfattelse af sjælen som noget kvasifysisk. Faktisk kan jeg ikke finde noget etnografisk eksempel på en fuldstændig immateriel sjæl, når jeg går igennem den omfattende litteratur om animistiske forestillinger blandt indfødte jægerfolk. Åke Hultkrantz (1953) gør en lignende observation i sit kompendium om nordamerikanske sjælsforestillinger: „Sjælen ... tillægges en ikke ubetydelig grad af rå legemlighed, som til tider har overrasket europæerne“ (op.cit.391). Emile Durkheim (1995 [1912]) påpegede det samme i sit studie af de australske indfødte: „Det ville være en misforståelse at opfatte kroppen som en slags bolig, hvor sjælen lever ... Tværtimod er den bundet til kroppen med de strammeste bånd“ (op.cit.254). „Sjælen opfattes altid som noget fysisk“ (op.cit.225). 
Dette understreger det forhold, at der i den animistiske tænkning ikke synes at være en klar adskillelse mellem krop og sjæl, mellem det ydre og indre. Hvordan kan vi så tale om samspillet mellem kroppen og sjælen i perspektivismen?

Aparedica Vilaças undersøgelse af, hvordan sjælen er forbundet til kroppen blandt wari'-folket i Amazonas, er et passende sted at starte. Blandt wari' „ligger sjælens virkelighed i andres øjne“ (2005:449), som derfor ikke er en subjektiv oplevelse, men relationelt defineret (op.cit.456). En given persons sjæl, menneskelig eller ikke-menneskelig, er synlig for andre personer, men altid i form af en krop. Hvis disse andre, som ser på sjælen, tilhører en anden slags mennesker, som for eksempel et dyr eller en ånd, vil de se den som radikalt forskellig fra den måde, hvorpå det menneskelige subjekt ser sin egen krop (op.cit.455). Således repræsenterer sjælen en persons evne til at antage en mangfoldighed af kropslige former som set fra et eksternt perspektiv. Dog gør Vilaça sig umage med at påpege, at i Amazon-perspektivismen udgør de forskellige perspektiver aldrig til en helhed - således er „enhver totalisering af kroppen umulig“"(op.cit.458).

Kan vi med Vilaça (2005:455) konkludere, at den animistiske sjæl i virkeligheden er kroppen, hvis aktualisering som en særlig form for krop afhænger af øjnene, der betragter den? Jeg tror, at vi stadig står over for et problem, der er forbundet med det grundlæggende antropologiske spørgsmål om „kulturel oversættelse“.

Indtil videre har jeg ukritisk fulgt Tylor, Viveiros de Castros og Vilaça, blandt mange andre antropologer, og brugt ordet ,sjæl“ til at beskrive indfødte folks forestillinger. Men dette ord er helt tydeligt vildledende. Sjælen i vores jødiskkristne diskurs er en integreret del af et ontologisk modsætningsforhold mellem „ånd“ og „stoflighed“, hvilket indebærer, at sjælen er immateriel. Men som vi netop har set, er sjælen overhovedet ikke immateriel i den indfødte forståelse. Faktisk tværtimod: Den er en krop! Selv væsener, der siges at jage „sjæle“, som for eksempel ke'let blandt tjuktjerne (Bogoras 1904-9:294-5) og abasylar blandt jukagirerne (Willerslev 2007:82), ser aldrig sjæle. De ser „,kød“, „,rensdyr“, „,ææl““ og ,elg“ - så hvad de rent faktisk ser, er tydeligvis kroppe.

Indebærer det så, at der i animistisk tænkning slet ikke findes noget usynligt og luftigt, som bedre kan beskrives med ordet sjæl? Jeg vil vove at påstå, at det gør der. Men for at forklare det, har vi brug for netop det totalitetsperspektiv på kroppen, som Vilaça benægter er en del af perspektivismen.

\section{Det totale perspektiv}

Lad mig starte med en lille afstikker ind i filosofien, nærmere bestemt til Maurice Merleau-Pontys teori om synet, der indebærer et radikalt brud med vores sund 
fornuft-forståelse af synet som noget, der er placeret der, hvor vores øjne er (2002 [1945]).

Eftersom vores opfattelse af et objekt altid dannes fra et perspektiv eller et andet, kan vi aldrig se objektet i sin helhed, men kun delvist. Der vil altid være en „skjult side“, som forbliver usynlig fra vores direkte perspektiv. Ikke desto mindre formoder vi umiddelbart, at der er mere af objektet, end hvad vores „blotte øje“" tillader os at se. Hvis det ikke var tilfældet, ville vi opleve objektet som en todimensionel facade og ikke som en fuld tredimensionel virkelighed. Så på en måde opfatter vi objektet som havende sider, der er skjult for vores umiddelbare syn. Merleau-Ponty (op.cit.79) hævder, at det sker, fordi genstanden, som vi betragter, er viklet ind i et net af omgivende perspektiver fra de omkringliggende genstande, der så at sige tilbyder os „øjne“ hvorfra vi kan „se“ objektets skjulte sider. Vi oplever derfor objektet som havende dybde og volumen og ser det ikke som blot fladt. Med andre ord ser vi ikke kun ved hjælp af vores eget syn, men er afhængige af et anonymt totalsyn, som går forud for os (Willerslev \& Ulturgasheva 2007).

Merleau-Ponty kalder dette primordiale syn ,perspektivet alle steder fra“. Selv om vi kan prøve at forestille os dette totalsyn, kan vi i sagens natur aldrig se tingene i deres helhed, simpelthen fordi det at se, som kropsligt væsen, altid indebærer et konkret perspektiv. Alligevel kan vi ikke undvære totalperspektivet. Det danner så at sige den usynlige baggrund, der gør det muligt for ting at træde ud i tredimensionel synlighed. Som Merleau-Ponty (2000 [1964]:187) udtrykker det: „Essensen af det synlige er at have en beklædning af usynlighed ... som det gør nærværende gennem et vist fravær.“ Med andre ord, mens ,,perspektivet alle steder fra" indebærer, at verden ses i klar og utvetydig synlighed - det vil sige en verden blotlagt $i$ absolut gennemsigtighed - er det et perspektiv, der nødvendigvis må ,skjule sig“, for at den synlige verden kan åbenbare sig for vores øjne. Som sådan er ,perspektivet alle steder fra“ et perspektiv, som vi kun kan sanses ,negativt“, det vil sige ved fravcer (Holbraad \& Willerslev 2007:334). Jeg vil vove at påstå, at dette anonyme totalsyn, der befinder sig her, der og alle vegne på én og samme gang, finder sin ækvivalent i jukagirernes og tjuktjernes forestillinger om Pon og Va'irgin og i de andre såkaldte „højguder“ i animistiske samfund. Disse diffuse og uhåndgribelige åndelige væsner repræsenterer et førperspektivistisk syn, præget af anonymitet og totalitet, hvilket, som vi har set, udgør ethvert kropsligt perspektivs bagvedliggende vitale og animerende princip (Willerslev 2006:34). Faktisk forklarer det, hvorfor Pon og Va'irgin går under så intetsigende navne som „,noget“ og „noget eksisterende“, fordi de er intet mindre end det ,umulige“: den guddommelige totalitet, der ser uden grænser og afstande i en enkelt bevægelse. Det er derfor heller ikke overraskende, at der ikke 
er nogen myter, som beskriver dem, og ingen ofringer eller bønner adresseret til dem, da det ville indebære, at man reducerede dem til en form for legemligt væsen med specifikke og derfor begrænsede visuelle kapaciteter.

Spørgsmålet, der uundgåeligt melder sig, er: Hvis Pon og Va'irgin er det totale perspektiv, som ser alt, hvad ser de så rent faktisk? I perspektivismens terminologi kan de kun se et, nemlig tingenes ,sjæl“". Pon og Va'irgin med deres anonyme og ubegrænsede syn definerer således sjælen, som er intet mindre end kroppen set $\mathrm{i}$ hele sin totalitet eller absolutte synlighed, så intet er skjult - det vil sige kroppen set fra alle sider, i alle relationer, på én og samme gang (Holbraad \& Willerslev 2007:335). Sjælen er, med andre ord, kroppen fastfrosset i et øjeblik af total synlighed. Vilaça (2005:458), har derfor helt ret empirisk set, når hun hævder, at inden for perspektivismen er ,enhver totalisering af kroppen umulig“ (op.cit.458). Men analytisk set har hun ikke ret. Uden et anonymt total syn, effektueret igennem væsener som Pon og Va'irgin, ville der ikke være en perspektivistisk idé om sjælen til at begynde med. En logisk følge heraf er, at Tylors tese om, at tanker om sjælen tilhører en anden udviklingsfase end monoteismen, er helt forkert. Uden bevidstheden om et slags altseende væsen - om end ganske vagt erkendt kunne der som sådan ikke være nogen idé om en animistisk sjæl.

\section{Essensen af jagtbytte}

Med disse tanker i baghovedet, vil jeg vende tilbage til min tolkning af Den Dansende Troldmand, malet i en fjern fortid i en hule i Sydfrankrig. Vi så, at de øvrige afbildede væsener er byttedyr, sådan som de er set fra den menneskelige jægers perspektiv. Det vil sige, at de er repræsenteret som faktiske dyrekroppe, overdådigt belæsset med kød og fedt, og de er da også blevet skudt på, som skulle de nedlægges. Hvorfor skulle Den Dansende Troldmand være anderledes? Jeg vil foreslå, at også han repræsenterer jagtbytte eller rettere den generelle idé om jagtbytte. Det indebærer nemlig en person, menneskelig såvel som ikke-menneskelig, set fra alle perspektiver på én og samme gang, hvilket er intet mindre end kroppen set fra det guddommelige totalperspektiv. Det forklarer, hvorfor figuren er omgivet af en collage af dyr, for de leverer de mange perspektiver. Det forklarer også, hvorfor figuren er repræsenteret som en mosaik af dyrekroppe, hvor hvert eksternt perspektiv ser hans krop som en eller anden slags dyr. Desuden forklarer det, hvorfor figuren ligesom står på spring, for hvem ville ikke forsøge at flygte ud af kredsen af dræberblikke? Sidst, men ikke mindst forklarer det, hvorfor vi under figurens sammensatte krop fornemmer en luftig eller spøgelsesagtig stoflighed. Jeg forestiller mig, at det må være de palæolitiske jægeres forsøg på at udstille sjælen, som er hinsides skildring, men som de ikke desto mindre søgte 
at gøre „nærværende gennem et vist fravær“. Den Dansende Troldmand er altså essensen af ideen om sjælen som bytte, set med guddommelige øjne.

Nærmere kan jeg nok ikke komme det guddommelige, der har den vanskelighed, at det ikke kan observeres eller beskrives direkte. Jeg håber dog at have overbevist jer om, at det guddommelige er andet og mere end tågesnak og primitiv overtro, at det har virkelige virkninger og effekter i menneskets liv, som videnskabsfolk ikke skal ignorere, men bør tage seriøst.

Hvis I nu ved forelæsningens slutning stadig ikke er blevet klogere på det guddommelige, så fortvivl ikke. Måske har I i stedet lyst til at vrinske som en hest, brøle som en løve og hyle som ulv - ligesom Den Dansende Troldmand. I så fald er I besjælet af det guddommelige blik, og det er langt mere eventyrligt, end hvad jeg har kunnet forklare med ord. Ord er, når det kommer til stykket, skabt til at beskrive afgrænsede ting - den naturlige verden, mennesker og så videre. Så at bruge dem til at indfange det guddommelige, som jo er endeløst og overskrider enhver menneskelig forestilling, er i sagens natur en håbløs opgave. Og gudskelov for det. Kunne vi sige, hvad det guddommelige er, ville tanken ophøre, talen forstumme og forskningen gå i stå.

\section{Litteratur}

Århem, Kaj

1996 The Cosmic Food Web: Human-nature Relatedness in the Northwest Amazon. I: P. Descola \& G. Pálsson (eds.): Nature and Society: Anthropological Perspectives. London: Routledge.

Bogoras, Waldemar

1904-9 The Chukchee (ed.): F. Boas. Memoir of the American Museum of Natural History. Vol. VII. New York: American Museum of Natural History.

Breuil, Henri

1958 Les cavernes du volp: Trois Freres. Paris, Arts et Metiérs.

Brightman, Robert

1993 Grateful Prey: Rock Cree Human-animal Relationships. Berkeley, CA: University of California Press.

Burnham, Dorothy, K.

1992 To Please the Caribou: Painted Caribou-skin Coats Worn by the Naskapi, Montagnais, and Cree Hunters of the Quebec-Labrador Peninsula. Seattle: University of Washington Press.

Caputo, John D.

2002 Introduction: Who Comes after the God of Metaphysics. I: J.D. Caputo (ed.): The Religious. Oxford: Blackwell Publishers.

de Castro, Eduardo Viveiros

1998 Cosmological Deixis and Amerindian Perspectivism. Journal of the Royal Anthropological Institute (N.S.) 4:469-88. 
Clottes, Jean \& David Lewis-Williams

1997 Schamanen: Trance und Magie in der höhlenkunst der steinzeit. Ostfildern: Jan Thorbecke Verlag.

Descola, Philippe

1986 La nature domestique: symbolism et praxis dans l'écologie des Achuar. Paris: Maison des Sciences de l'Homme.

Durkheim, Emile

1995 [1912] The Elementary Forms of Religious Life. New York: The Free Press.

Evans-Pritchard, Edward Evan

1956 Nuer Religion. Oxford: Oxford University Press.

Fausto, Carlos

2007 Feasting on People: Eating Animals and Humans in Amazonia.

Current Anthropology 48(4):497-530.

Fienup-Riordan, Ann

1994 Boundaries and Passages: Rule and Ritual in Yup'ik Eskimo Oral Tradition. Norman: University of Oklahoma Press.

Gimbutas, Marija

1989 The Language of the Goddess: Unearthing the Hidden Symbols of Western Civilization. San Francisco: Harper and Row.

Goldman, Irving

1975 The Mouth of Heaven: An Introduction to Kwakiutl Religious Thought.

New York: Wiley-Interscience.

Hallowell, Irving A.

1960 Ojibwa Ontology, Behaviour and World View. I: S. Diamond (ed.): Culture in History: Essays in Honor of Paul Radin. New York: Colombia University Press.

Holbraad, Martin \& Rane Willerslev

2007 Afterword. Transcendental Perspectivism: Anonymous Viewpoints from Inner Asia. Inner Asia 9(2).

Howell, Signe

1989 Society and Cosmos: Chewong of Peninsular Malaysia. Chicago \& London: The University of Chicago Press.

Howitt, Alfred W.

1884 On some Australian Beliefs. Journal of the Royal Anthropological Society 13: $185-98$

Hultcrantz, Åge

1953 Conceptions of the Soul Among North American Indians. Monograph Series No.

1. Stockholm: Ethnographical Museum of Sweden.

Jochelson, Waldemar

1908 The Koryak. I: F. Boas (ed.): Memoir of the American Museum of Natural History. Vol. VI. New York: American Museum of Natural History.

1926 The Yukaghir and the Yukaghized Tungus. I: F. Boas (ed.): New York: American Museum of Natural History.

Lang, Andrew

1898 The Making of Religion. Charleston, SC: Forgotten Books. 
Lewis-Williams, David

2002 The Mind in the Cave: Consciousness and the Origin of Art. Thames \& Hudson.

Merleau-Ponty, Maurice

2000 [1964] Eye and Mind. I: J.M. Edie: The Primacy of Perception and other Essays on Phenomenological Psychology, the Philosophy of Art, History and Politics. Evanston, IL: Northwestern University Press.

2002 [1945] Phenomenology of Perception. London \& New York: Routledge.

Pedersen, Morten A.

2001 Totemism, Animism and North Asian Indigenous Ontologies. Journal of the Royal Anthropological Institute 7(3):411-27.

Pedersen, Morten A., Rebecca Empson \& Caroline Humphrey (eds.)

2007 Inner Asian Perspectivisms. Inner Asia 10(1):141-52.

Rasmussen, Knud

1929 Intellectual Culture of the Iglulik Eskimos. Report of the Fifth Thule Expedition 1921-24, vol. 7, no. 1. København: Gyldendalske Boghandel, Nordisk Forlag.

Smith, Jonathan Z.

1982 The Unknown God: Myth in History. Imagining Religion: From Babylon to Jonestown. Chicago \& London: The University of Chicago Press.

Stewart, H.

1979 Looking at Indian Art of the Northwest Coast. Seattle: University of Washington Press.

Stocking, George W., Jr.

1995 After Tylor: British Social Anthropology 1888-1951. Madison: The University of Wisconsin Press.

Tanner, Adrian

1979 Bringing Home Animals: Religious Ideology and Mode of Production of the Mistassini Cree Hunters. St John's: Memorial University of Newfoundland.

Tylor, Edward, B.

1958 [1871] Primitive Culture: Researches into the Development of Mythology, Philosophy, Religion, Language, Art, and Custom. Vol. 1 \& 2. London: John Murray, Albemarle Street.

1891 The Limits of Savage Religion. Journal of the Royal Anthropological Institute 21: 283-301.

Valeri, Valerio

2000 The Forest of Taboos: Morality, Hunting, and Identity among the Huaulu of the Moluccas. Madison: University of Wisconsin Press.

Vilaça, Aparedica

2005 Chronically Unstable Bodies: Reflections on Amazonian Corporalities. Journal of the Royal Anthropological Institute (N.S.) 11:445-64

Vitebsky, Piers

1995 The Shaman: Voyages of the Soul, Trance, Ecstasy and Healing from Siberia to the Amazon. London: Macmillan in association with Duncan Baird Publishers. 
Willerslev, Rane

$2004 \quad$ Not Animal, Not-not Animal: Hunting, Imitation and Empathetic Knowledge among the Siberian Yukaghirs. The Journal of the Royal Anthropological Institute, 10(3):629-52.

2006 To Have the World at a Distance: Reconsidering the Significance of Vision for Social Anthropology. I: C. Grasseni (ed.): Skilled Vision: Between Apprenticeship and Standards. Oxford: Berghahn Books.

2007 Soul Hunters: Hunting, Animism, and Personhood among the Siberian Yukaghirs. Berkeley, CA: University of California Press.

2009 The Optimal Sacrifice: A Study of Voluntary Death among the Siberian Chukchi. American Ethnologist 36(4):693-704.

Willerslev, Rane \& Olga Ulturgasheva

2007

The Sable Frontier: The Siberian Fur Trade as Montage. Cambridge Anthropology 26(2):79-100.

[i tryk] Revisiting the Animism vs. Totemism Debate: Fabricating Persons among Eveny and Chukchi of Northeastern Siberia. I: M. Brightman, V.E. Grotti \& O. Ulturgasheva (eds.): Shamanism in Rainforest and Tundra: Personhood in the Shamanic Ecologies of Contemporary Amazonia and Siberia, London \& New York: Berghahn Books. 